\title{
The microRNA expression signature of pancreatic ductal adenocarcinoma by RNA sequencing: anti-tumour functions of the microRNA-216 cluster
}

\author{
Keiichi Yonemori ${ }^{1}$, Naohiko Seki ${ }^{2}$, Tetsuya Idichi ${ }^{1}$, Hiroshi Kurahara ${ }^{1}$, Yusaku \\ Osako' ${ }^{1}$, Keiichi Koshizuka ${ }^{2}$, Takayuki Arai ${ }^{2}$, Atsushi Okato ${ }^{2}$, Yoshiaki Kita ${ }^{1}$, Takaaki \\ Arigami $^{1}$, Yuko Mataki ${ }^{1}$, Yuko Kijima ${ }^{1}$, Kosei Maemura ${ }^{1}$ and Shoji Natsugoe ${ }^{1}$ \\ ${ }^{1}$ Department of Digestive Surgery, Breast and Thyroid Surgery, Graduate School of Medical Sciences, Kagoshima University, \\ Sakuragaoka, Kagoshima 890-8520, Japan \\ ${ }^{2}$ Department of Functional Genomics, Chiba University Graduate School of Medicine, Chuo-ku, Chiba 260-8670, Japan \\ Correspondence to: Naohiko Seki, email: naoseki@faculty.chiba-u.jp \\ Keywords: pancreatic ductal adenocarcinoma, microRNA, expression signature, miR-216b-3p, FOXQ1 \\ Received: February 07, $2017 \quad$ Accepted: June 26, $2017 \quad$ Published: July 26, 2017 \\ Copyright: Yonemori et al. This is an open-access article distributed under the terms of the Creative Commons Attribution License \\ 3.0 (CC BY 3.0), which permits unrestricted use, distribution, and reproduction in any medium, provided the original author and \\ source are credited.
}

\section{ABSTRACT}

We analysed the RNA sequence-based microRNA (miRNA) signature of pancreatic ductal adenocarcinoma (PDAC). Aberrantly expressed miRNAs were successfully identified in this signature. Using the PDAC signature, we focused on 4 clustered miRNAs, miR-216a-5p, miR-216a-3p, miR-216b-5p and miR-216b-3p on human chromosome 2p16.1. All members of the miR-216 cluster were significantly reduced in PDAC specimens. Ectopic expression of these miRNAs suppressed cancer cell aggressiveness, suggesting miR-216 cluster as anti-tumour miRNAs in PDAC cells. The impact of miR-216b-3p (passenger strand of pre-miR-216b) on cancer cells is still ambiguous. Forkhead box Q1 (FOXQ1) was directly regulated by miR-216b-3p and overexpression of FOXQ1 was confirmed in clinical specimens. High expression of FOXQ1 predicted a shorter survival of patients with PDAC by Kaplan-Meier analysis. Loss-of-function assays showed that cancer cell migration and invasion activities were significantly reduced by siFOXQ1 transfectants. We investigated pathways downstream from FOXQ1 by using genome-wide gene expression analysis. Identification of the miR-216-3p/FOXQ1-mediated network in PDAC should enhance understanding of PDAC aggressiveness at the molecular level.

\section{INTRODUCTION}

Pancreatic ductal adenocarcinoma (PDAC) is a highly lethal malignancy, as the 5 -year survival rate after diagnosis is only $5 \%[1,2]$. PDAC cells are extremely aggressive, and more than $50 \%$ of patients develop local recurrence or distant metastasis after curative resection $[3$, 4]. Recently developed molecularly targeted therapeutics have not shown beneficial effects in patients with PDAC $[5,6]$. The molecular pathogenesis of the aggressive phenotype in PDAC remains unclear. Therefore, in order to improve disease outcomes in PDAC patients, it is necessary to define the molecular pathogenesis underlying the aggressiveness of PDAC using advanced genomic approaches.

microRNAs (miRNAs) belong to a family of short, non-coding RNAs transcribed from the human genome. Their discovery suggested new directions for the study of human cancer pathogenesis [7]. A unique characteristic of miRNAs is the ability of a single miRNA to tune a large number of RNA transcripts in human cells [8]. Thus, dysregulated miRNA expression can disrupt tightly controlled RNA networks and increase the aggressiveness of cancer cells. Numerous studies have indicated that 
miRNAs are aberrantly expressed in several cancers, including PDAC [9-12].

We have been identified anti-tumour miRNAs and their mediated novel cancer networks based on the miRNA expression signatures in various cancers [13-20]. Construction of miRNA signatures using clinical specimens is a first step towards identification of dysregulated miRNAs and their resultant clinical characteristics. Current RNA sequencing methods offer superior analytical approaches for studying the transcriptome. We recently showed that the passenger strand of $m i R-145-3 p$ acted as an anti-tumour miRNA through regulating of several oncogenic genes in bladder cancer and lung cancer [21, 22]. Moreover, we showed that both strands of pre-miR-139 (miR-139-5p and $m i R$ $139-3 p)$ targeted matrix metalloprotease 11 in bladder cancer [23]. The involvement of passenger strand miRNAs in the regulation of cellular processes is a novel concept in RNA research.

In this study, we analysed the miRNA expression signature of PDAC clinical specimens by RNA sequencing. Using the PDAC signature, we focused on 4 clustered miRNAs, miR-216a-5p, miR-216a-3p, miR$216 b-5 p$ and $m i R-216 b-3 p$ on human chromosome $2 \mathrm{p} 16.1$ and investigated their functional significance in PDAC pathogenesis. Transcription of all members of the miR216 cluster was significantly reduced in PDAC specimens, and ectopic expression of these miRNAs suppressed cancer cell aggressiveness. We further investigated the target genes of $m i R-216$. The resultant data provide novel insights into the molecular pathogenesis of PDAC.

\section{RESULTS}

\section{Construction of expression signature and identification of downregulated miRNAs in PDAC}

Libraries of small RNAs (from seven PDAC tissues and four normal pancreatic tissues) were analysed by using RNA sequencing technology. The patients' characteristics are shown in Table 1. Initially, 16,930,437 to 24,733,299 raw sequence reads were produced for the libraries. After filtering for low quality and adaptors sequence reads, from $10,615,842$ to $23,407,926$ clean small RNA reads were obtained (Table 2). Differentially expressed miRNAs by RNA sequence were summarized in Supplementary Tables 1 and 2.

We focused on 23 downregulated miRNAs (Table 3 ), and these miRNAs were mapped on the human genome. We found that $m i R-217, m i R-216 a-5 p /-3 p$ and miR216b-5p/-3p were close together and were defined as clustered miRNAs. Because the role of the $m i R-216$ cluster had not been reported in PDAC, we focused on it in further studies. As shown in Figure 1, miR-216a-
$5 p /-3 p$ and $m i R 216 b-5 p /-3 p$ are located within the same chromosomal region ( $2 \mathrm{q} 16.1)$.

\section{Expression levels of the miR-216 family in PDAC specimens and cell lines}

We evaluated expression levels of the miR-216 family in PDAC tissues $(\mathrm{n}=24)$, normal pancreatic tissues $(n=14)$ and two PDAC cell lines (PANC-1 and SW 1990). Patient clinicopathological features are summarized in Table 1. The expression levels of $m i R$ 216a-5p, miR-216a-3p, miR-216b-5p and miR-216b-3p were significantly lower in tumour tissues than in normal pancreatic tissues (Figure 2). It was not recognized the significant relationships between any of the clinical parameters (i.e., TNM stage, metastasis or survival rate) and expression levels of any member of the $m i R-216-$ family (data not shown).

To elucidate molecular mechanisms of low expression of the clustered miRNAs, miR-216a-5p, $m i R-216 a-3 p, m i R-216 b-5 p$ and $m i R-216 b-3 p$ in PDAC cells, PANC-1 and SW1990 cells were treated with the demethylating agent [5-aza-2'-deoxycytidine (5-aza$\mathrm{dC})$ ]. Expression levels of all clustered miRNAs in PDAC cells were significantly elevated by 5 -aza-dc treatment (Supplementary Figure 1). These data suggested that DNA methylation might cause silencing of these clustered miRNAs in PDAC cells.

\section{Expression of $m i R-216$ family members and the effects on cell growth, migration and invasion in PDAC cell lines}

The functional roles of the miR-216-family were performed by using restoration of mature miRNAs assays. Functional assays showed that proliferation, migration and invasion activities of cancer cells were significantly suppressed in miR-216a-5p, miR-216a-3p, miR-216b$5 p$ and $m i R-216 b-3 p$ transfectants compared with mock or miR-control transfectants (Figure 3). Present results suggested that the $m i R-216$ family could have anti-tumour functions in PDAC cells. Among the miR-216 family, miR$216 b-3 p$ markedly inhibited PDAC cell aggressiveness (Figure 3).

We hypothesized that passenger strand of $m i R-216-$ $3 p$ may be incorporated into and function as part of the RISC structure. To check this hypothesis, we performed immunoprecipitation with antibody targeting Ago2, which plays a pivotal role in the RISC. After transfection with $m i R-216-3 p$, Ago2-bound miRNAs were isolated, and RT-qPCR was carried out to determine whether $m i R-216-3 p$ bound to Ago2. Expression of $m i R-216-3 p$ levels were significantly higher than those of mock and miRNA control transfected cells (Supplementary Figure 2). Moreover, expression levels of $m i R-216 a-5 p, m i R-$ 
Table 1: Clinical features of PDAC patients

\begin{tabular}{|c|c|c|c|c|c|c|c|c|}
\hline No. & Age & Sex & $\mathbf{T}$ & $\mathbf{N}$ & M & Stage & Recurrence & Remarks \\
\hline $\mathrm{T} 1$ & 44 & M & 3 & 1 & 0 & IIB & $(+)$ & deep sequencing \\
\hline $\mathrm{T} 2$ & 76 & M & 4 & 1 & 0 & III & $(+)$ & deep sequencing \\
\hline $\mathrm{T} 3$ & 67 & M & 3 & 1 & 0 & IIB & $(+)$ & deep sequencing \\
\hline $\mathrm{T} 4$ & 65 & M & 3 & 1 & 0 & IIB & $(+)$ & deep sequencing \\
\hline T5 & 56 & $\mathrm{~F}$ & 3 & 1 & 1 & IV & $(+)$ & deep sequencing \\
\hline T6 & 83 & $\mathrm{~F}$ & 3 & 0 & 0 & IIA & $(-)$ & deep sequencing \\
\hline $\mathrm{T} 7$ & 66 & $\mathrm{~F}$ & 3 & 1 & 0 & IIB & $(-)$ & deep sequencing \\
\hline N1 & 77 & F & & & & & & deep sequencing \\
\hline $\mathrm{N} 2$ & 65 & $\mathrm{~F}$ & & & & & & deep sequencing \\
\hline $\mathrm{N} 3$ & 71 & $\mathrm{~F}$ & & & & & & deep sequencing \\
\hline N4 & 83 & $\mathrm{~F}$ & & & & & & deep sequencing \\
\hline PCR_T1 & 67 & M & 3 & 1 & 0 & IIB & $(+)$ & RT-PCR \\
\hline PCR_T2 & 78 & $\mathrm{~F}$ & 3 & 0 & 0 & IIA & $(-)$ & RT-PCR \\
\hline PCR_T3 & 58 & F & 3 & 0 & 0 & IIA & $(+)$ & RT-PCR \\
\hline PCR_T4 & 42 & $\mathrm{~F}$ & 3 & 1 & 0 & IIB & $(+)$ & RT-PCR \\
\hline PCR_T5 & 56 & $\mathrm{~F}$ & 3 & 0 & 0 & IIA & $(+)$ & RT-PCR \\
\hline PCR_T6 & 79 & F & 3 & 0 & 0 & IIA & $(+)$ & RT-PCR \\
\hline PCR_T7 & 63 & F & 3 & 0 & 0 & IIA & $(+)$ & RT-PCR \\
\hline PCR_T8 & 52 & $\mathrm{M}$ & 3 & 0 & 0 & IIA & $(-)$ & RT-PCR \\
\hline PCR_T9 & 78 & F & 3 & 1 & 0 & IIB & $(+)$ & RT-PCR \\
\hline PCR_T10 & 66 & F & 3 & 1 & 0 & IIB & $(-)$ & RT-PCR \\
\hline PCR_T11 & 66 & F & 3 & 0 & 0 & IIA & $(-)$ & RT-PCR \\
\hline PCR_T12 & 67 & M & is & 0 & 0 & 0 & $(+)$ & RT-PCR \\
\hline PCR_T13 & 74 & M & 4 & 0 & 0 & III & $(-)$ & RT-PCR \\
\hline PCR_T14 & 74 & F & 3 & 1 & 0 & IIB & $(-)$ & RT-PCR \\
\hline PCR_T15 & 65 & F & 3 & 1 & 0 & IIB & $(-)$ & RT-PCR \\
\hline PCR_T16 & 78 & $\mathrm{~F}$ & 3 & 0 & 0 & IIA & $(-)$ & RT-PCR \\
\hline PCR_T17 & 42 & $\mathrm{M}$ & 4 & 1 & 0 & III & $(+)$ & RT-PCR \\
\hline PCR_T18 & 44 & M & 3 & 1 & 0 & IIB & $(+)$ & RT-PCR \\
\hline PCR_T19 & 76 & M & 3 & 1 & 0 & IIB & $(+)$ & RT-PCR \\
\hline PCR_T20 & 70 & M & 3 & 0 & 0 & IIA & $(+)$ & RT-PCR \\
\hline PCR_T21 & 78 & $\mathrm{~F}$ & 1 & 0 & 0 & I & $(-)$ & RT-PCR \\
\hline PCR_T22 & 56 & M & 1 & 0 & 0 & I & $(+)$ & RT-PCR \\
\hline PCR_T23 & 65 & M & 3 & 0 & 0 & IIA & $(-)$ & RT-PCR \\
\hline PCR_T24 & 70 & F & 3 & 1 & 0 & IIB & $(+)$ & RT-PCR \\
\hline PCR_N1 & 76 & M & & & & & & RT-PCR \\
\hline PCR_N2 & 58 & $\mathrm{~F}$ & & & & & & RT-PCR \\
\hline PCR_N3 & 67 & M & & & & & & RT-PCR \\
\hline PCR_N4 & 67 & M & & & & & & RT-PCR \\
\hline PCR_N5 & 42 & F & & & & & & RT-PCR \\
\hline PCR_N6 & 71 & F & & & & & & RT-PCR \\
\hline
\end{tabular}

(Continued) 


\begin{tabular}{|c|c|c|c|c|c|c|c|c|}
\hline No. & Age & Sex & $\mathbf{T}$ & $\mathbf{N}$ & M & Stage & Recurrence & Remarks \\
\hline PCR_N7 & 60 & M & & & & & & RT-PCR \\
\hline PCR_N8 & 56 & F & & & & & & RT-PCR \\
\hline PCR_N9 & 67 & $\mathrm{M}$ & & & & & & RT-PCR \\
\hline PCR_N10 & 85 & F & & & & & & RT-PCR \\
\hline PCR_N11 & 66 & F & & & & & & RT-PCR \\
\hline PCR_N12 & 66 & F & & & & & & RT-PCR \\
\hline PCR_N13 & 44 & $\mathrm{M}$ & & & & & & RT-PCR \\
\hline PCR_N14 & 63 & $\mathrm{~F}$ & & & & & & RT-PCR \\
\hline IHC_1 & 72 & M & 3 & 1 & 0 & IIB & $(+)$ & $\mathrm{IHC}$ \\
\hline IHC_2 & 80 & M & 3 & 1 & 0 & IIB & $(-)$ & $\mathrm{IHC}$ \\
\hline IHC_3 & 75 & F & 3 & 1 & 0 & IIB & $(-)$ & IHC \\
\hline IHC_4 & 60 & M & 4 & 0 & 0 & III & $(+)$ & IHC \\
\hline IHC_5 & 52 & M & 3 & 0 & 0 & IIA & $(+)$ & IHC \\
\hline IHC_6 & 50 & M & 4 & 0 & 0 & III & $(+)$ & $\mathrm{IHC}$ \\
\hline IHC_7 & 68 & $\mathrm{~F}$ & 4 & 0 & 0 & III & $(-)$ & $\mathrm{IHC}$ \\
\hline IHC_8 & 77 & $\mathrm{~F}$ & 4 & 0 & 0 & III & $(+)$ & IHC \\
\hline IHC_9 & 57 & M & 3 & 1 & 0 & IIB & $(+)$ & IHC \\
\hline IHC_10 & 44 & $\mathrm{M}$ & 3 & 1 & 0 & IIB & $(+)$ & IHC \\
\hline IHC_11 & 68 & M & 4 & 1 & 0 & III & $(+)$ & $\mathrm{IHC}$ \\
\hline IHC_12 & 76 & $\mathrm{M}$ & 4 & 1 & 0 & III & $(+)$ & IHC \\
\hline IHC_13 & 54 & M & 3 & 1 & 0 & IIB & $(+)$ & IHC \\
\hline IHC_14 & 74 & $\mathrm{~F}$ & 3 & 1 & 0 & IIB & $(+)$ & IHC \\
\hline IHC_15 & 67 & M & 3 & 1 & 0 & IIB & $(+)$ & IHC \\
\hline IHC_16 & 76 & $\mathrm{~F}$ & 3 & 0 & 0 & IIA & $(-)$ & IHC \\
\hline IHC_17 & 54 & $\mathrm{M}$ & 3 & 1 & 0 & IIB & $(+)$ & IHC \\
\hline IHC_18 & 75 & $\mathrm{~F}$ & 3 & 0 & 0 & IIA & $(-)$ & IHC \\
\hline IHC_19 & 77 & F & 2 & 0 & 0 & IB & $(-)$ & IHC \\
\hline IHC_20 & 66 & $\mathrm{M}$ & 3 & 1 & 0 & IIB & $(+)$ & IHC \\
\hline IHC_21 & 69 & $\mathrm{M}$ & 3 & 1 & 0 & IIB & $(+)$ & IHC \\
\hline IHC_22 & 69 & M & 2 & 0 & 0 & IB & $(+)$ & IHC \\
\hline IHC_23 & 50 & F & 3 & 1 & 0 & IIB & $(+)$ & IHC \\
\hline IHC_24 & 67 & F & 3 & 1 & 0 & III & $(+)$ & IHC \\
\hline IHC_25 & 78 & M & 3 & 1 & 0 & IIB & $(+)$ & IHC \\
\hline IHC_26 & 70 & $\mathrm{M}$ & 3 & 1 & 0 & IIB & $(+)$ & IHC \\
\hline IHC_27 & 59 & M & 3 & 0 & 0 & IIA & $(-)$ & IHC \\
\hline IHC_28 & 74 & F & 3 & 1 & 0 & IIB & $(+)$ & IHC \\
\hline IHC_29 & 75 & $\mathrm{M}$ & 3 & 0 & 0 & IIA & $(+)$ & IHC \\
\hline IHC_30 & 58 & $\mathrm{~F}$ & 3 & 0 & 0 & IIA & $(+)$ & IHC \\
\hline IHC_31 & 74 & M & 3 & 1 & 0 & IIB & $(+)$ & IHC \\
\hline IHC_32 & 59 & F & 3 & 1 & 0 & IIB & $(+)$ & IHC \\
\hline IHC_33 & 69 & F & 3 & 0 & 0 & IIA & $(-)$ & IHC \\
\hline IHC_34 & 65 & $\mathrm{~F}$ & 4 & 1 & 0 & III & $(+)$ & IHC \\
\hline IHC_35 & 85 & F & 3 & 1 & 0 & IIB & $(+)$ & IHC \\
\hline
\end{tabular}


Table 2: Annotation of reads aligned to small RNAs

\begin{tabular}{|c|c|c|c|c|c|c|c|c|c|c|c|c|c|c|}
\hline \multirow{2}{*}{$\begin{array}{l}\text { PDAC } \\
\text { samples }\end{array}$} & \multicolumn{2}{|c|}{ \#T1 } & \multicolumn{2}{|c|}{ \#T2 } & \multicolumn{2}{|c|}{ \#T3 } & \multicolumn{2}{|c|}{ \#T4 } & \multicolumn{2}{|c|}{ \#T5 } & \multicolumn{2}{|c|}{ \#T6 } & \multicolumn{2}{|c|}{ \#T7 } \\
\hline & Count & $(\%)$ & Count & $(\%)$ & Count & $(\%)$ & Count & $(\%)$ & Count & $(\%)$ & Count & $(\%)$ & Count & $(\%)$ \\
\hline Total & 17591803 & 100 & 15426965 & 100 & 16586380 & 100 & 10615842 & 100 & 18965893 & 100 & 23407926 & 100 & 12845961 & 100 \\
\hline exon & 1018127 & 5.79 & 809048 & 5.24 & 184851 & 1.11 & 155240 & 1.46 & 540260 & 2.85 & 459079 & 1.96 & 263018 & 2.05 \\
\hline $\begin{array}{l}\text { exon_- } \\
\text { antisense }\end{array}$ & 9 & 0.00 & 4 & 0.00 & 5 & 0.00 & 6 & 0.00 & 3 & 0.00 & 4 & 0.00 & 10 & 0.00 \\
\hline miRNA & 3045486 & 17.31 & 4835786 & 31.35 & 3464002 & 20.88 & 1721101 & 16.21 & 2740681 & 14.45 & 2664925 & 11.38 & 3152583 & 24.54 \\
\hline rRNA & 489091 & 2.78 & 1588798 & 10.30 & 216971 & 1.31 & 440961 & 4.15 & 181910 & 0.96 & 583477 & 2.49 & 490623 & 3.82 \\
\hline tRNA & 829391 & 4.71 & 110334 & 0.72 & 1076000 & 6.49 & 141156 & 1.33 & 1067387 & 5.63 & 542804 & 2.32 & 263598 & 2.05 \\
\hline snRNA & 24109 & 0.14 & 31039 & 0.20 & 9153 & 0.06 & 14372 & 0.14 & 18154 & 0.10 & 28997 & 0.12 & 24883 & 0.19 \\
\hline snoRNA & 848025 & 4.82 & 478768 & 3.10 & 617055 & 3.72 & 260963 & 2.46 & 440008 & 2.32 & 1211925 & 5.18 & 691475 & 5.38 \\
\hline lenRNA & 77 & 0.00 & 56 & 0.00 & 30 & 0.00 & 24 & 0.00 & 273 & 0.00 & 78 & 0.00 & 85 & 0.00 \\
\hline ribozyme & 18531 & 0.11 & 8449 & 0.05 & 7111 & 0.04 & 6490 & 0.06 & 7255 & 0.04 & 16746 & 0.07 & 10127 & 0.08 \\
\hline sRNA & 15 & 0.00 & 17 & 0.00 & 17 & 0.00 & 17 & 0.00 & 29 & 0.00 & 27 & 0.00 & 28 & 0.00 \\
\hline Unannotated & 1489059 & 8.46 & 2684735 & 17.40 & 717881 & 4.33 & 5430607 & 51.16 & 2993173 & 15.78 & 8071185 & 34.48 & 4184768 & 32.58 \\
\hline Unmapped & 9829883 & 55.88 & 4879931 & 31.63 & 10293304 & 62.06 & 2444905 & 23.03 & 10976760 & 57.88 & 9828679 & 41.99 & 3764763 & 29.31 \\
\hline \multirow{2}{*}{$\begin{array}{l}\text { Normal } \\
\text { pancreas } \\
\text { samples }\end{array}$} & \multicolumn{3}{|c|}{ \#N1 } & \multicolumn{4}{|c|}{$\# \mathbf{N} 2$} & \multicolumn{3}{|c|}{$\# \mathbf{N 3}$} & \multicolumn{4}{|c|}{ \#N4 } \\
\hline & \multicolumn{2}{|c|}{ Count } & $(\%)$ & \multicolumn{2}{|c|}{ Count } & \multicolumn{2}{|l|}{$(\%)$} & \multicolumn{2}{|l|}{ Count } & $(\%)$ & \multicolumn{2}{|c|}{ Count } & \multicolumn{2}{|c|}{$(\%)$} \\
\hline Total & \multicolumn{2}{|c|}{16535900} & 100 & \multicolumn{2}{|c|}{20967863} & \multicolumn{2}{|l|}{100} & \multicolumn{2}{|l|}{17370365} & 100 & \multicolumn{2}{|c|}{18447846} & \multicolumn{2}{|c|}{100} \\
\hline exon & 281 & 15 & 1.70 & & 70434 & 1.29 & & 576712 & & 3.32 & 9635 & & 5.2 & \\
\hline exon_antisense & 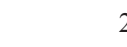 & & 0.00 & & 9 & 0.00 & & 39 & & 0.00 & 24 & & 0.0 & \\
\hline miRNA & 4247 & 206 & 25.68 & & 331251 & 20.66 & & 3534149 & & 20.35 & 5133 & 67 & 27.8 & \\
\hline rRNA & 659 & 76 & 3.99 & & 10278 & 1.48 & & 1457154 & & 8.39 & 8104 & & 4.3 & \\
\hline tRNA & 334 & 61 & 2.02 & & 145451 & 5.46 & & 418994 & & 2.41 & 5680 & & 3.0 & \\
\hline snRNA & 191 & & 0.12 & & 22558 & 0.11 & & 28997 & & 0.17 & 251 & & 0.1 & \\
\hline snoRNA & 703 & 93 & 4.26 & & 80199 & 4.20 & & 714087 & & 4.11 & 6414 & & 3.4 & \\
\hline lcnRNA & 4 & & 0.00 & & 39 & 0.00 & & 15 & & 0.00 & 72 & & 0.0 & \\
\hline ribozyme & 39 & & 0.02 & & 7398 & 0.04 & & 11294 & & 0.07 & 925 & & 0.0 & \\
\hline sRNA & 2 & & 0.00 & & 31 & 0.00 & & 37 & & 0.00 & 32 & & 0.0 & \\
\hline Unannotated & 5295 & 677 & 32.03 & & 66037 & 4.61 & & 2152804 & & 12.39 & 1710 & 26 & 9.2 & \\
\hline Unmapped & 4990 & 576 & 30.18 & & 034178 & 62.16 & & 8476083 & & 48.80 & 8585 & 84 & 46.5 & \\
\hline
\end{tabular}

$216 a-3 p$ and $m i R-216 b-5 p$ were same levels of mock and miRNA control transfectants (Supplementary Figure 2).

\section{Identification of genes regulated by $m i R-216 b-3 p$ in PDAC cells}

To elucidate the molecular mechanisms and pathways regulated by anti-tumour $m i R-216 b-3 p$ in PDAC cells, we used a combination of gene expression and in silico analyses. Figure 4 presents the strategy for narrowing down the target genes of $m i R-216 b-3 p$.
In gene expression analyses, 439 and 806 genes were downregulated $\left(\log _{2}\right.$ ratio <-1.0) in PANC-1 and SW 1990 $m i R-216 b-3 p$ transfectants, respectively, in comparison with control transfectants (GEO accession number, GSE82108). Next, we pared down the list of genes using the TargetscanHuman and GEO database (GEO accession number, GSE15471). We found that 20 genes were putatively targeted by $m i R-216 b-3 p$ in PANC-1 and SW 1990 miR-216b-3p transfectants.

Among these candidate genes, 6 genes (PLAU, FOXQ1, PGM2L1, MBOAT2, PERP and UHMK1) were 
Table 3: Differentially expressed miRNAs in PDAC by RNA seqencing

\begin{tabular}{|c|c|c|c|c|c|}
\hline \multicolumn{6}{|c|}{ Downregulated miRNAs in PDAC } \\
\hline miRNA & miRBase_accession & Locus & $\begin{array}{c}\text { LogFC (tumor/ } \\
\text { normal) }\end{array}$ & $P$ value & FDR \\
\hline$h s a-m i R-216 a-5 p$ & MIMAT0000273 & $\operatorname{chr} 2: 56216155-56216176$ & -3.22 & 0.0033 & 0.4602 \\
\hline hsa-miR-802 & MIMAT0004185 & $\operatorname{chr} 21: 37093030-37093052$ & -3.17 & 0.0001 & 0.0901 \\
\hline hsa-miR-3186-3p & MIMAT0015068 & $\operatorname{chr17:79418142-79418162}$ & -3.16 & 0.0072 & 0.5030 \\
\hline hsa-miR-217 & MIMAT0000274 & chr2:56210155-56210177 & -3.13 & 0.0034 & 0.4602 \\
\hline hsa-miR-2114-5p & MIMAT0011156 & chrX:149396251-149396272 & -3.08 & 0.0033 & 0.4602 \\
\hline$h s a-m i R-216 b-5 p$ & MIMAT0004959 & chr2:56227899-56227920 & -2.77 & 0.0286 & 0.9691 \\
\hline$h s a-m i R-3186-5 p$ & MIMAT0015067 & chr17:79418178-79418199 & -2.70 & 0.0230 & 0.9200 \\
\hline$h s a-m i R-216 b-3 p$ & MIMAT0026721 & chr2:56227859-56227882 & -2.58 & 0.0008 & 0.1722 \\
\hline$h s a-m i R-6510-3 p$ & MIMAT0025477 & $\operatorname{chr17:39673418-39673438}$ & -2.57 & 0.0098 & 0.6010 \\
\hline$h s a-m i R-122-5 p$ & MIMAT0000421 & chr18:56118320-56118341 & -2.51 & 0.0207 & 0.8791 \\
\hline$h s a-m i R-412-3 p$ & MIMAT0002170 & chr14:101531837-101531859 & -2.42 & 0.0393 & 1.0000 \\
\hline hsa-miR-129-1-3p & MIMAT0004548 & chr7:127847973-127847994 & -2.40 & 0.0011 & 0.2082 \\
\hline$h s a-m i R-216 a-3 p$ & MIMAT0022844 & $\operatorname{chr} 2: 56216116-56216137$ & -2.38 & 0.0214 & 0.8791 \\
\hline$h s a-m i R-135 a-3 p$ & MIMAT0004595 & $\operatorname{chr} 3: 52328248-52328269$ & -2.37 & 0.0008 & 0.1722 \\
\hline$h s a-m i R-148 a-5 p$ & MIMAT0004549 & chr7:25989580-25989601 & -2.30 & 0.0009 & 0.1722 \\
\hline$h s a-m i R-891 a-5 p$ & MIMAT0004902 & chrX:145109359-145109380 & -2.25 & 0.0053 & 0.5030 \\
\hline hsa-miR-190b & MIMAT0004929 & chr1:154166189-154166209 & -2.12 & 0.0003 & 0.1429 \\
\hline$h s a-m i R-148 a-3 p$ & MIMAT0000243 & chr7:25989542-25989563 & -2.12 & 0.0001 & 0.0901 \\
\hline$h s a-m i R-211-5 p$ & MIMAT0000268 & $\operatorname{chr} 15: 31357298-31357319$ & -2.10 & 0.0084 & 0.5545 \\
\hline hsa-miR-1224-5p & MIMAT0005458 & chr3:183959193-183959211 & -2.05 & 0.0450 & 1.0000 \\
\hline$h s a-m i R-338-5 p$ & MIMAT0004701 & chr17:79099723-79099744 & -2.02 & 0.0002 & 0.0956 \\
\hline hsa-miR-129-2-3p & MIMAT0004605 & chr11:43603000-43603021 & -2.01 & 0.0090 & 0.5650 \\
\hline hsa-miR-137 & MIMAT0000429 & chr1:98511647-98511669 & -2.01 & 0.0874 & 1.0000 \\
\hline \multicolumn{6}{|c|}{ Upregulated miRNAs in PDAC } \\
\hline $\operatorname{miRNA}$ & miRBase_accession & Locus & $\begin{array}{c}\text { LogFC (tumor/ } \\
\text { normal) }\end{array}$ & P value & FDR \\
\hline$h s a-m i R-6887-3 p$ & MIMAT0027675 & $\operatorname{chr} 19: 35613648-35613668$ & 4.13 & 0.0007 & 0.1722 \\
\hline$h s a-m i R-4713-5 p$ & MIMAT0019820 & chr15:51534397-51534418 & 4.04 & 0.0039 & 0.4750 \\
\hline hsa-miR-615-5p & MIMAT0004804 & chr12:54427751-54427772 & 3.61 & 0.0053 & 0.5030 \\
\hline hsa-miR-1248 & MIMAT0005900 & chr3:186504464-186504490 & 3.50 & 0.0002 & 0.0956 \\
\hline$h s a-m i R-490-3 p$ & MIMAT0002806 & chr7:136587989-136588010 & 3.47 & 0.0386 & 1.0000 \\
\hline hsa-miR-184 & MIMAT0000454 & $\operatorname{chr15:79502182-79502203}$ & 3.46 & 0.0467 & 1.0000 \\
\hline$h s a-m i R-196 a-5 p$ & MIMAT0000226 & $\begin{array}{l}\text { chr17:46709894-46709915 } \\
\text { chr12:54385546-54385567 }\end{array}$ & 3.24 & 0.0103 & 0.6146 \\
\hline hsa-miR-187-3p & MIMAT0000262 & chr18:33484798-33484819 & 3.05 & 0.0195 & 0.8676 \\
\hline$h s a-m i R-6516-3 p$ & MIMAT0030418 & $\operatorname{chr17:75085551-75085572}$ & 3.03 & 0.0046 & 0.5030 \\
\hline hsa-miR-490-5p & MIMAT0004764 & chr7:136587952-136587971 & 2.95 & 0.0457 & 1.0000 \\
\hline$h s a-m i R-3131$ & MIMAT0014996 & chr2:219923447-219923469 & 2.94 & 0.0112 & $\begin{array}{c}0.6428 \\
\text { (Continued) }\end{array}$ \\
\hline
\end{tabular}




\begin{tabular}{|c|c|c|c|c|c|}
\hline \multicolumn{6}{|c|}{ Upregulated miRNAs in PDAC (Continue) } \\
\hline$h s a-m i R-4697-3 p$ & MIMAT0019792 & chr11:133768401-133768424 & 2.90 & 0.0070 & 0.5030 \\
\hline hsa-miR-615-3p & MIMAT0003283 & chr12:54427794-54427815 & 2.86 & 0.0001 & 0.0901 \\
\hline hsa-miR-196b-5p & MIMAT0001080 & chr7:27209147-27209168 & 2.73 & 0.0009 & 0.1722 \\
\hline$h s a-m i R-187-5 p$ & MIMAT0004561 & chr18:33484834-33484855 & 2.70 & 0.0610 & 1.0000 \\
\hline hsa-miR-6886-3p & MIMAT0027673 & chr19:11224187-11224207 & 2.68 & 0.0247 & 0.9200 \\
\hline hsa-miR-650 & MIMAT0003320 & chr22:23165285-23165305 & 2.67 & 0.0138 & 0.7105 \\
\hline hsa-miR-492 & MIMAT0002812 & chr12:95228203-95228225 & 2.66 & 0.0257 & 0.9200 \\
\hline hsa-miR-6744-5p & MIMAT0027389 & $\operatorname{chr11:1277840-1277858}$ & 2.65 & 0.0169 & 0.8201 \\
\hline hsa-miR-6805-5p & MIMAT0027510 & chr19:55899554-55899575 & 2.55 & 0.0603 & 1.0000 \\
\hline hsa-miR-935 & MIMAT0004978 & chr19:54485616-54485638 & 2.53 & 0.0059 & 0.5030 \\
\hline$h s a-m i R-4485$ & MIMAT0019019 & chr11:10529824-10529843 & 2.53 & 0.0192 & 0.8676 \\
\hline hsa-miR-196a-3p & MIMAT0004562 & chr12:54385583-54385604 & 2.52 & 0.0627 & 1.0000 \\
\hline hsa-miR-1 & MIMAT0000416 & $\begin{array}{l}\text { chr18:19408976-19408997 } \\
\text { chr20:61151558-61151579 }\end{array}$ & 2.48 & 0.0697 & 1.0000 \\
\hline$h s a-m i R-4768-5 p$ & MIMAT0019920 & chrX:17444012-17444033 & 2.42 & 0.0567 & 1.0000 \\
\hline hsa-miR-6887-5p & MIMAT0027674 & chr19:35613609-35613631 & 2.39 & 0.0749 & 1.0000 \\
\hline$h s a-m i R-181 b-3 p$ & MIMAT0022692 & chr1:198828016-198828036 & 2.34 & 0.0827 & 1.0000 \\
\hline hsa-miR-4745-5p & MIMAT0019878 & chr19:804941-804963 & 2.32 & 0.0491 & 1.0000 \\
\hline$h s a-m i R-4724-5 p$ & MIMAT0019841 & $\operatorname{chr17:29861911-29861933~}$ & 2.25 & 0.0950 & 1.0000 \\
\hline hsa-miR-6814-3p & MIMAT0027529 & chr21:43166932-43166953 & 2.15 & 0.0664 & 1.0000 \\
\hline$h s a-m i R-203 b-3 p$ & MIMAT0019814 & chr14:104583765-104583787 & 2.10 & 0.0518 & 1.0000 \\
\hline$h s a-m i R-143-5 p$ & MIMAT0004599 & chr5:148808507-148808528 & 2.09 & 0.0019 & 0.3270 \\
\hline hsa-miR-6850-5p & MIMAT0027600 & chr8:146017355-146017376 & 2.09 & 0.1212 & 1.0000 \\
\hline$h s a-m i R-549 a$ & MIMAT0003333 & chr15:81134334-81134354 & 2.06 & 0.1130 & 1.0000 \\
\hline hsa-miR-133a-3p & MIMAT0000427 & $\begin{array}{l}\text { chr18:19405673-19405694 } \\
\text { chr20:61162177-61162198 }\end{array}$ & 2.06 & 0.0275 & 0.9691 \\
\hline hsa-miR-3661 & MIMAT0018082 & chr5:133561468-133561489 & 2.03 & 0.0800 & 1.0000 \\
\hline hsa-miR-4649-5p & MIMAT0019711 & chr7:44150450-44150473 & 2.02 & 0.0661 & 1.0000 \\
\hline$h s a-m i R-31-3 p$ & MIMAT0004504 & chr9:21512120-21512141 & 2.02 & 0.0195 & 0.8676 \\
\hline hsa-miR-6862-5p & MIMAT0027625 & $\begin{array}{l}\text { chr16:28402346-28402367 } \\
\text { chr16:28735578-28735599 }\end{array}$ & 2.01 & 0.0770 & 1.0000 \\
\hline
\end{tabular}

significantly associated with poor prognosis of patients with PDAC (Table 4 and Supplementary Figure 3). Past studies showed that aberrant expressed FOX-family of transcription factors were involved in several types of cancers, however, functional significance of FOXQ1 in PDAC is still unclear.

We determined that FOXQ1 was upregulated in clinical PDAC samples using qRT-PCR (Figure 5A). Negative correlations between $m i R-216 b-3 p$ expression and FOXQ1 mRNA expression were found using Spearman's rank test $(R=-0.5160, P=0.0006$, Figure 5B). Kaplan-Meier survival curves constructed from PDAC patients in the TCGA dataset showed that patient groups with high expression of FOXQ1 had significantly shorter overall survival $(P=0.0070$; Figure 5D). The TCGA dataset was analysed by OncoLnc database (http:// www.oncolnc.org/)[24].

\section{Expression of FOXQ1 in PDAC clinical specimens}

We validated the expression of FOXQ1 in PDAC clinical specimens using immunohistochemistry. A total of 35 specimens were evaluated, and 12 samples were classified as having high expression of FOXQ1. Clinicopathological characteristics are summarized in 
Table 1. Table 5 shows the correlation between FOXQ1 expression and various clinicopathological factors. High FOXQ1 expression was significantly associated with increased lymph node metastasis. Furthermore, patients with high FOXQ1 expression had significantly shorter OS than those with low FOXQ1 expression $(P=0.0007)$ (Figure 5E).
Moreover, we categorized patients into two groups, with adjuvant chemotherapy or without adjuvant chemotherapy. Regardless of the treatment, patients with high FOXQ1 expression were associated with poor prognosis (Supplementary Figure 4).

We confirmed the expression of FOXQ1 in PDAC clinical specimens using immunohistochemistry.

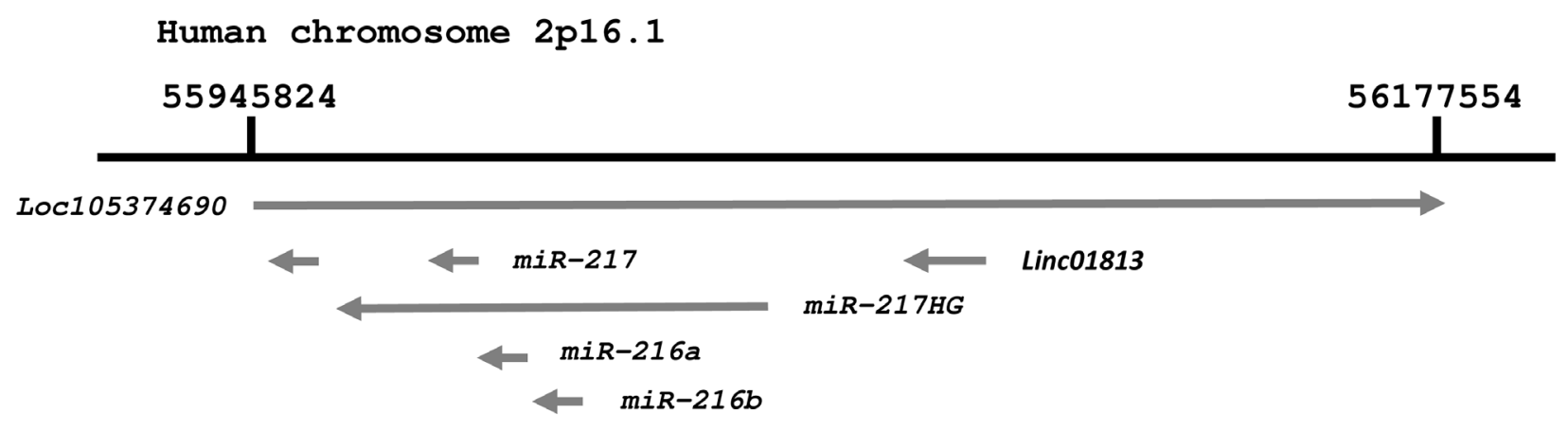

Stem-loop sequence hsa-miR-216a

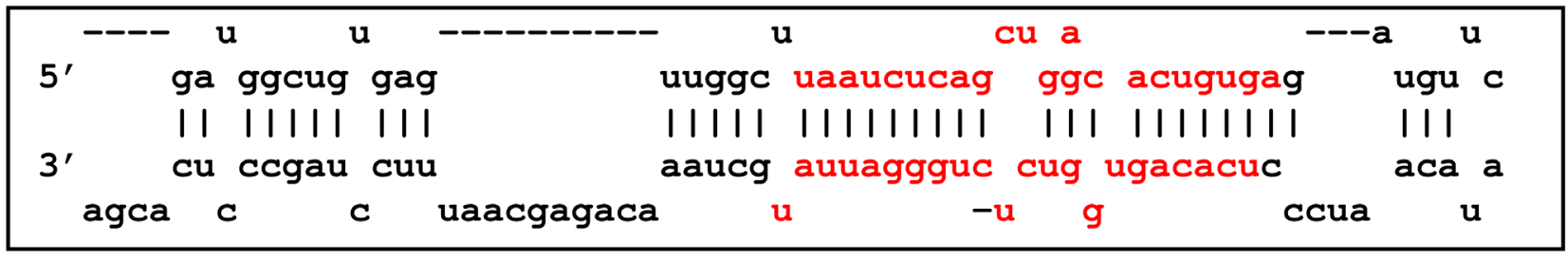

Stem loop sequence hsa-miR-216b

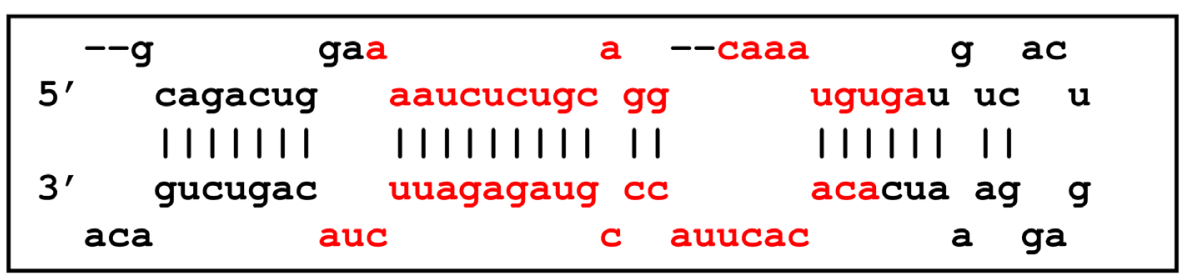

\section{Mature sequences}

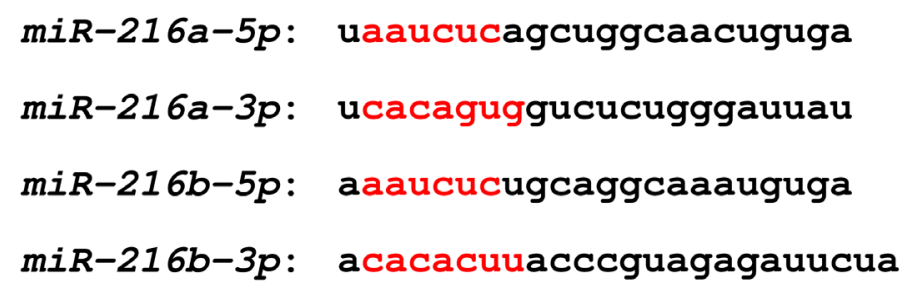

Figure 1: Schematic representation of the human miR-216 family in chromosomal location. The $m i R-216$ family members and $m i R-217$ are located on human chromosome 2q16.1. Mature miRNAs, $m i R-216 a-5 p$ (guide strand) and $m i R-216 a-3 p$ (passenger strand) are derived from pre-miR-216a. Likewise pre-miR-216a, miR-216b-5p (guide strand) and $m i R-216 b-3 p$ (passenger strand) are derived from pre-miR-216b. Seed sequences of $m i R-216 a-5 p$ and $m i R-216 b-5 p$ are identical. In contrast, seed sequences of $m i R-216 a-3 p$ and $m i R-216 b-$ $3 p$ are independent sequences. 

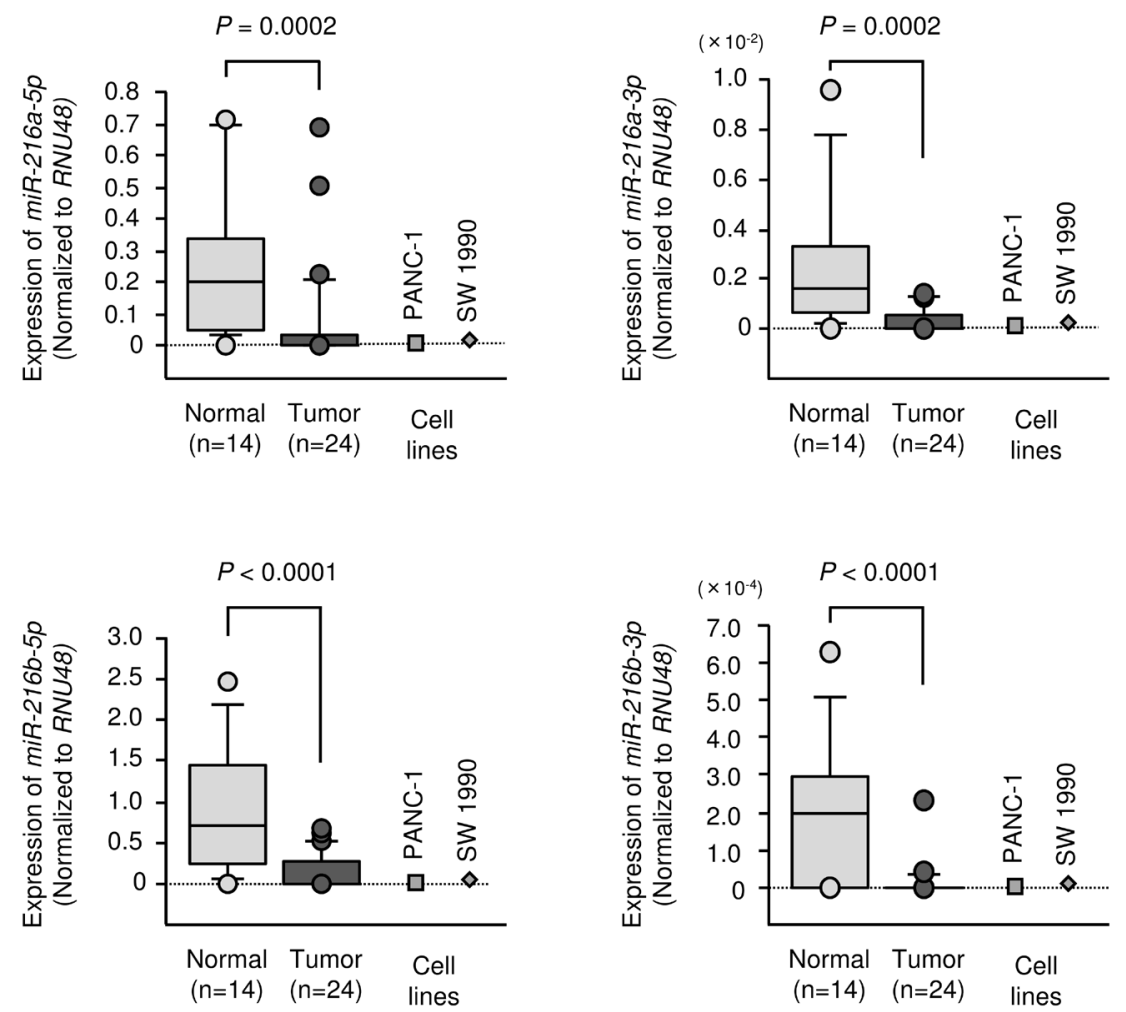

Figure 2: Expression levels of $\boldsymbol{m i R}-216$ family members. Expression levels of $m i R-216$ family members in clinical specimens and PDAC cell lines were determined using qRT-PCR. Data were normalized to RNU48 expression.
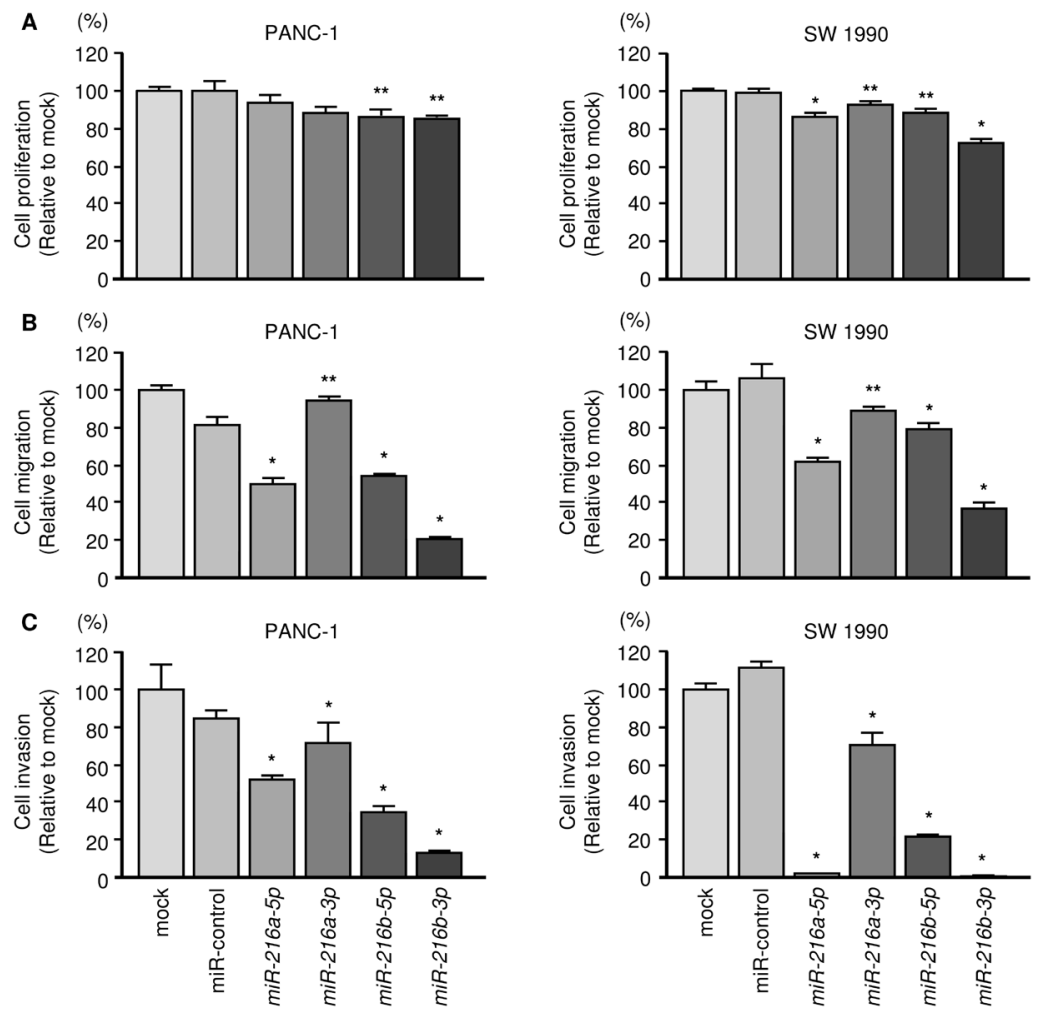

Figure 3: Effects of $m i R-216 a-5 p$, $m i R-216 a-3 p$, $m i R-216 b-5 p$ and $m i R-216 b-3 p$ transfection into PDAC cells. (A) Cell growth was determined using XTT assays $72 \mathrm{~h}$ after transfection with $10 \mathrm{nM} \mathrm{miR-216}$ family members. *, $P<0.0001$; **, $P<0.05$. (B) Cell migration activity was determined using BD Falcon Cell Culture Inserts. ${ }^{*}, P<0.0001$. (C) Cell invasion activity was determined using Matrigel invasion assays. *, $P<0.0001$. 
Expression of FOXQ1 was detected in in ductal carcinoma, not in normal ductal cells, acinar cells and islets cells (Supplementary Figure 5).

\section{FOXQ1 is a direct target of $m i R-216 b-3 p$ in PDAC cells}

We performed qRT-PCR to validate $m i R-216 b-3 p$ mediated reduction of $F O X Q 1 \mathrm{mRNA}$ expression in PDAC cell lines. Our studies demonstrated that FOXQ1 mRNA was markedly reduced in $m i R-216 b-3 p$ transfectants compared to mock or miR-control transfectants $(\mathrm{P}<$ 0.0001, Figure 6A). FOXQ1 protein expression was also repressed in the $m i R-216 b-3 p$ transfectants (Figure 6B).

Target prediction databases indicated the presence of 2 putative target sites in the 3'-UTR of FOXQ1
(Figure 6C). To determine whether FOXQ1 mRNA had a functional target site, we performed luciferase reporter assays. Compared with the miR-control, luminescence intensity was significantly reduced by transfection with $m i R-216 b-3 p$ at its target site, position 720-727 in the 3'UTR of FOXQ1 (Figure 6C).

\section{Effects of silencing FOXQ1 on PDAC cell lines}

To investigate the oncogenic functions of $F O X Q 1$ in PDAC cells, we carried out knockdown assays by using si-FOXQ1. First, we evaluated the knockdown efficiency achieved by si-FOXQ1 transfection of PDAC cell lines. We used 2 types of si-FOXQ1 ( siFOXQ1-1 and si-FOXQ1-2) in this study. Both siRNAs effectively downregulated FOXQ1 expression in both

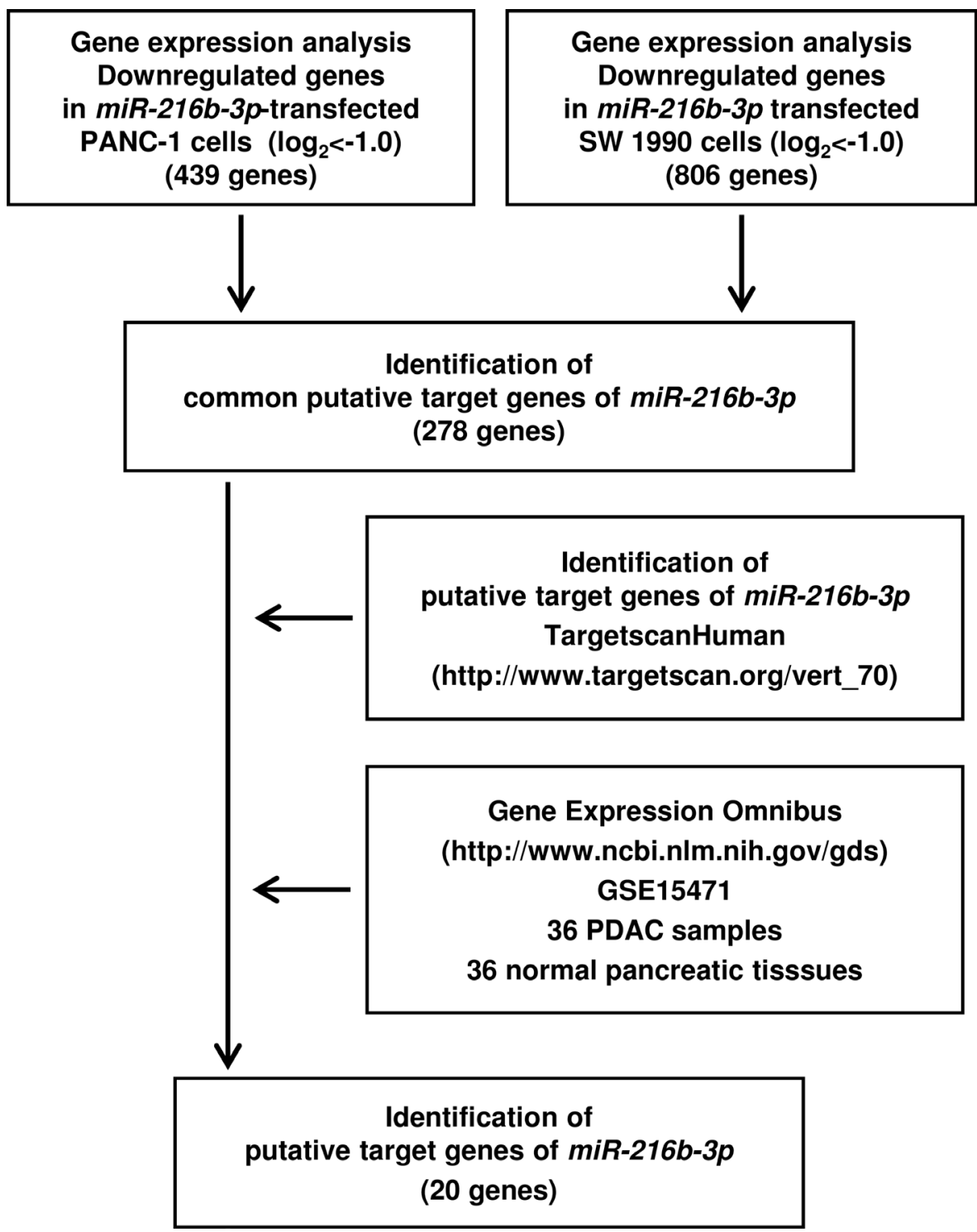

Figure 4: Flow chart illustrating the analytic strategy for $m i R-216 b-3 p$ target genes. Strategy for identification of putative candidate genes regulated by $m i R-216 b-3 p$ in PDAC cells. Approach to identifying $m i R-216 b-3 p$ target genes by in silico analysis of genome-wide gene expression, TargetScan and GEO database analysis of $m i R-216 b-3 p$ transfectants and PDAC clinical specimens. 
Table 4: Candidate target genes regulated by $m i R-216 b-3 p$ in PDAC

\begin{tabular}{|c|c|c|c|c|c|c|c|c|}
\hline \multirow{2}{*}{$\begin{array}{l}\text { Entrez } \\
\text { gene } \\
\text { ID }\end{array}$} & \multirow[t]{2}{*}{$\begin{array}{c}\text { Gene } \\
\text { symbol }\end{array}$} & \multirow[t]{2}{*}{ Description } & \multicolumn{2}{|c|}{$\begin{array}{l}\text { Microarray } \\
\left(\log _{2} \text { ratio) }\right. \\
m i R-216 b-3 p\end{array}$} & \multirow[b]{2}{*}{ Average } & \multirow{2}{*}{$\begin{array}{c}\begin{array}{c}\text { Target site } \\
\text { (Targetscan) }\end{array} \\
m i R-216 b-3 p\end{array}$} & \multirow{2}{*}{ GEO } & \multirow[t]{2}{*}{$\begin{array}{c}\text { TCGA- } \\
\text { OncoLncKaplan } \\
\text { plot P-value }\end{array}$} \\
\hline & & & PANC-1 & SW1990 & & & & \\
\hline 5328 & $P L A U$ & $\begin{array}{l}\text { plasminogen activator, } \\
\text { urokinase }\end{array}$ & -1.03 & -1.10 & -1.06 & $(+)$ & 5.07 & 0.0161 \\
\hline 59345 & GNB4 & $\begin{array}{l}\text { guanine nucleotide binding } \\
\text { protein (G protein), beta } \\
\text { polypeptide } 4\end{array}$ & -1.76 & -2.27 & 2.01 & $(+)$ & 4.57 & 0.3330 \\
\hline 94234 & $F O X Q 1$ & forkhead box Q1 & -1.50 & -1.52 & -1.51 & $(+)$ & 3.88 & 0.0089 \\
\hline 9240 & PNMA1 & paraneoplastic Ma antigen 1 & -1.24 & -1.69 & -1.47 & $(+)$ & 3.27 & 0.9910 \\
\hline 283209 & $P G M 2 L 1$ & $\begin{array}{c}\text { phosphoglucomutase } \\
\text { 2-like } 1\end{array}$ & -1.67 & -1.91 & -1.79 & $(+)$ & 3.23 & 0.0477 \\
\hline 60481 & ELOVL5 & $\begin{array}{l}\text { ELOVL fatty acid } \\
\text { elongase } 5\end{array}$ & -1.50 & -2.77 & -2.13 & $(+)$ & 3.15 & 0.4970 \\
\hline 129642 & MBOAT2 & $\begin{array}{l}\text { membrane bound } \\
\text { O-acyltransferase domain } \\
\text { containing } 2\end{array}$ & -1.20 & -1.40 & -1.30 & $(+)$ & 2.92 & 0.0158 \\
\hline 5912 & $R A P 2 B$ & $\begin{array}{l}\text { RAP2B, member of RAS } \\
\text { oncogene family }\end{array}$ & -1.31 & -1.25 & -1.28 & $(+)$ & 2.74 & 0.1040 \\
\hline 5738 & PTGFRN & $\begin{array}{c}\text { prostaglandin F2 receptor } \\
\text { inhibitor }\end{array}$ & -1.57 & -2.00 & -1.79 & $(+)$ & 2.64 & 0.4350 \\
\hline 493 & $A T P 2 B 4$ & $\begin{array}{l}\text { ATPase, } \mathrm{Ca}++ \text { transporting, } \\
\text { plasma membrane } 4\end{array}$ & -1.45 & -2.27 & -1.86 & $(+)$ & 2.55 & 0.0966 \\
\hline 54492 & NEURL1B & $\begin{array}{l}\text { neuralized E3 ubiquitin } \\
\text { protein ligase 1B }\end{array}$ & -1.32 & -1.95 & -1.64 & $(+)$ & 2.36 & 0.0365 \\
\hline 64065 & PERP & $\begin{array}{l}\text { PERP, TP53 apoptosis } \\
\text { effector }\end{array}$ & -1.78 & -1.98 & -1.88 & $(+)$ & 2.33 & $<0.0001$ \\
\hline 160418 & TMTC3 & $\begin{array}{l}\text { transmembrane and } \\
\text { tetratricopeptide repeat } \\
\text { containing } 3\end{array}$ & -1.85 & -2.24 & -2.05 & $(+)$ & 2.30 & 0.9080 \\
\hline 55589 & $B M P 2 K$ & BMP2 inducible kinase & -1.04 & -1.54 & -1.29 & $(+)$ & 2.29 & 0.5220 \\
\hline 3977 & $L I F R$ & $\begin{array}{l}\text { leukemia inhibitory factor } \\
\text { receptor alpha }\end{array}$ & -1.96 & -2.09 & -2.03 & $(+)$ & 2.26 & $0.0062 *$ \\
\hline 10920 & COPS8 & $\begin{array}{l}\text { COP9 signalosome } \\
\text { subunit } 8\end{array}$ & -1.43 & -2.04 & -1.73 & $(+)$ & 2.20 & 0.2740 \\
\hline 9637 & FEZ2 & $\begin{array}{l}\text { fasciculation and elongation } \\
\text { protein zeta } 2 \text { (zygin II) }\end{array}$ & -1.03 & -1.28 & -1.15 & $(+)$ & 2.18 & 0.0974 \\
\hline 4286 & MITF & $\begin{array}{l}\text { microphthalmia-associated } \\
\text { transcription factor }\end{array}$ & -1.02 & -1.07 & -1.05 & $(+)$ & 2.17 & 0.0963 \\
\hline 29967 & $L R P 12$ & $\begin{array}{l}\text { low density lipoprotein } \\
\text { receptor-related protein } 12\end{array}$ & -1.32 & -2.22 & -1.77 & $(+)$ & 2.09 & 0.6200 \\
\hline 127933 & $U H M K 1$ & $\begin{array}{l}\text { U2AF homology motif } \\
\text { (UHM) kinase } 1\end{array}$ & -1.20 & -1.79 & -1.50 & $(+)$ & 2.04 & 0.0329 \\
\hline
\end{tabular}

\footnotetext{
* Poor prognosis with a low expression
} 
cell lines (Figure 7A and 7B). Functional assays showed that si-FOXQ1 transfection significantly reduced cell proliferation, migration and invasion compared with mock- or siRNA-control-transfected cells (Figure 7C-7E).

In contrast to loss-of-function assays, overexpression of FOXQ1 enhanced cancer cell migration and invasion in PANC-1 cells (Supplementary Figure 6).

\section{Investigation of FOXQ1-mediated downstream genes in PDAC cells}

Genome-wide gene expression (GEO accession number, GSE77790) and in silico analyses were performed to investigate the downstream genes mediated by FOXQ1 in a PDAC cell line (PANC-1) transfected with si-FOXQ1. A total of 18,277 genes were commonly downregulated $\left(\log _{2}\right.$ ratio $\left.<0\right)$. Further GEO analyses showed that 1,003 genes upregulated expression $\left(\log _{2}\right.$ ratio $>1.0)$ in GEO accession number GSE15471. Next, we assigned genes to KEGG pathways using the GENECODIS program and identified 261 pathways. In the top 3 pathways, 41 genes were significantly enriched (Supplementary Tables 3A and 3B).
TCGA database analyses demonstrated that high expression of 13 genes were significantly associated with poor survival in patients with PDAC (Supplementary Figure 7).

\section{DISCUSSION}

miRNA fine-tunes the expression control of protein coding/noncoding RNAs by repressing translation or cleaving RNA transcripts. Dysregulated miRNAs can disrupt tightly controlled RNA networks and thereby enhance the aggressiveness of cancer cells. Identification of dysregulated miRNAs and their targeted genes can improve our understanding of the molecular pathogenesis of human cancers. In that regard, we have identified novel RNA networks in several cancers [13-15].

In the present study, we newly constructed a miRNA expression signature of PDAC by RNA sequencing methods. Several miRNA signatures of PDAC were reported in which formalin-fixed paraffin-embedded tissue or fine-needle aspiration biopsies specimens were used for PCR or microarray-based applications [25-27]. Recently, we summarized dysregulated miRNAs in PDAC using information in public databases [12]. Downregulation
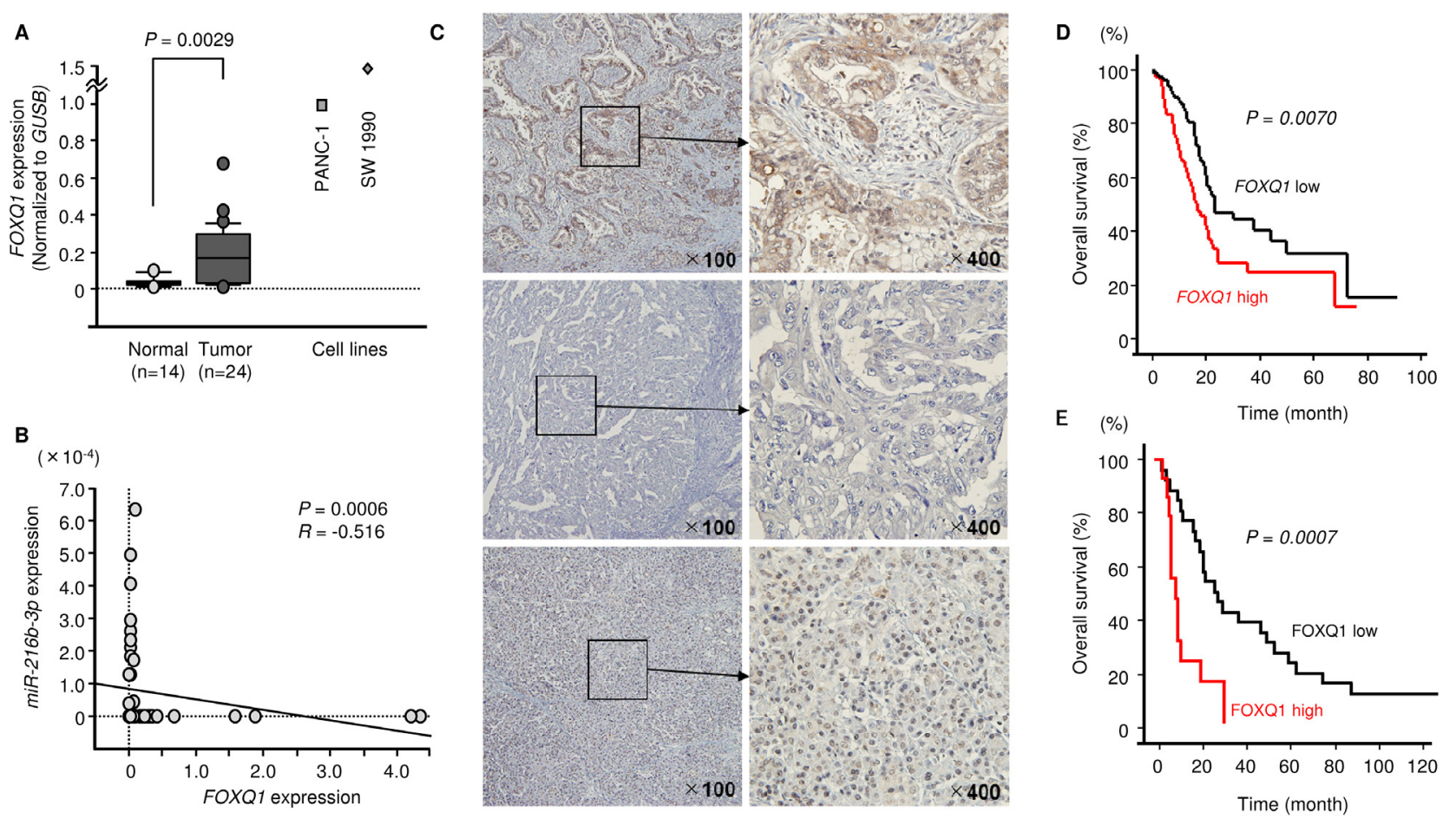

Figure 5: Expression of FOXQ1 (mRNA and protein) in PDAC and association of FOXQ1 with overall survival. (A) Expression levels of FOXQ1 in clinical specimens and PDAC cell lines were determined using qRT-PCR. Data were normalized to GUSB expression. (B) Correlation between miR-216-3p and FOXQ1 expression. (C) Immunohistochemical staining of FOXQ1 in PDAC clinical specimens. Overexpression of FOXQ1 was observed in cancer lesions (original magnification $\times 400$ ). In contrast, negative staining of FOXQ1 was observed in normal tissues. (IHC_13) Positively stained cancer lesion (T3N1M0). (IHC_18) Negatively stained cancer lesion (T3N0M0). (IHC_29) Negatively stained normal pancreas tissue. (D) TCGA-based large cohort study of high expression of FOXQ1 in 174 PDAC patients. ( $\overline{\mathbf{E}})$ Kaplan-Meier patient survival curves for overall survival rates based on FOXQ1 expression in 35 patients with PDAC. P-values were calculated using the log-rank test. 
Table 5: Correlation between the expression of FOXQ1 and clinicopathological factors in PDAC $(n=35)$

\begin{tabular}{|c|c|c|c|}
\hline \multirow{2}{*}{ Characteristic } & \multicolumn{2}{|c|}{ FOXQ1 } & \multirow{2}{*}{$P$} \\
\hline & $\operatorname{Low}(n=23)$ & High $(n=12)$ & \\
\hline Age $(y)^{a}$ & & & ${ }^{\mathrm{b}} \mathrm{NS}$ \\
\hline$\geq 60$ & 17 & 10 & \\
\hline$<60$ & 6 & 2 & \\
\hline \multicolumn{4}{|l|}{ Gender (n) } \\
\hline Male (20) & 13 & 7 & NS \\
\hline Female (15) & 10 & 5 & \\
\hline \multicolumn{4}{|l|}{ Tumor size (n) } \\
\hline$>40 \mathrm{~mm}(5)$ & 2 & 3 & NS \\
\hline$\leq 40 \mathrm{~mm}(30)$ & 21 & 9 & \\
\hline \multicolumn{4}{|c|}{ Lymph node metastasis (n) } \\
\hline No (11) & 10 & 1 & 0.0088 \\
\hline Yes (24) & 11 & 13 & \\
\hline \multicolumn{4}{|c|}{ Distant metastasis (n) } \\
\hline No (35) & 23 & 12 & NS \\
\hline \multicolumn{4}{|l|}{ TNM Stage (n) } \\
\hline I / II (27) & 18 & 9 & NS \\
\hline III / IV (8) & 5 & 3 & \\
\hline \multicolumn{4}{|l|}{ Recurrence (n) } \\
\hline No $(8)$ & 6 & 2 & NS \\
\hline Yes (27) & 17 & 10 & \\
\hline
\end{tabular}

${ }^{a}$ Values are mean $\pm \mathrm{SD}$.

${ }^{b} \mathrm{NS}$, not significant.

of $m i R-217, m i R-141, m i R-148 a$ and $m i R-375$ in PDAC tissues was commonly observed in PDAC tissues [12]. More recently, we demonstrated the anti-tumour roles of $m i R-375$ through its targeting of ZFP36L2 in PDAC cells [28]. Our present signature included several antitumour miRNAs that had been previously identified in PDAC, suggesting that our RNA-based signature was effective for identification of novel oncogenes and antitumour miRNAs in PDAC cells. These data may provide a benchmark for future studies of PDAC.

Our signature revealed that novel miRNAs were aberrantly expressed in PDAC cells. Among them, we focused on 4 clustered miRNAs, miR-216a-5p, miR-216a$3 p, m i R-216 b-5 p$ and $m i R-216 b-3 p$ located on human chromosome $2 \mathrm{p} 16.1$. Here, we showed that the clustered $m i R-216$ family has anti-tumour activity in PDAC. Those results suggest that the $m i R-216$ family is important in PDAC oncogenesis. Past studies showed that guide strands of $m i R-216 a-5 p$ and $m i R-216 b-5 p$ acted as anti-tumour miRNAs in several cancers $[29,30]$. On the other hand, the functional significance of passenger strands $m i R-216 a$ $3 p$ and $m i R-216 b-3 p$ has not been adequately analysed.

In miRNA biogenesis, the RNA guide strand from the duplex is recruited to the RNA-induced silencing complex (RISC) to target messenger RNAs, whereas the passenger strand is degraded and no functional activity $[31,32]$. Nevertheless, our present data showed that passenger strands $m i R-216 a-3 p$ and $m i R-216 b-3 p$ have anti-tumour functions in PDAC cells. Recently, we demonstrated that both strands of pre-miR-145 (miR$145-5 p$, guide strand, and $m i R-145-3 p$, passenger strand) were incorporated into RISC and function anti-tumour miRNAs by targeting several oncogenes in bladder and lung cancer cells [21,22]. The involvement of passenger strand miRNAs in the regulation of cellular processes is a novel concept in RNA research. 
The $\mathrm{Kras}^{\mathrm{G} 12 \mathrm{D}}$ oncogene is a key oncogenic mutation that is associated with development of PDAC [33, 34]. A recent study evaluated miRNA expression in the $\mathrm{Kras}^{\mathrm{G} 12 \mathrm{D}}$ transgenic mouse model of PDAC [35]. In that study, 3 miRNAs (miR-216a, miR-216b, and miR-217) were reduced in expression in the $\mathrm{Kras}^{\mathrm{G}}{ }^{12 \mathrm{D}}$ pancreas. Other study showed that significantly downregulation of $m i R$ $216 a$ and $m i R-217$ was detected in $\mathrm{Kras}^{\mathrm{G} 12 \mathrm{~d}}$;Pdx1-Cre mouse at 25 weeks [36]. Due to the lack of human clinical specimens from early stages of PDAC, the investigation is important to analyze expression patterns of miRNAs in early stages of PDAC by using mouse model. The molecular mechanisms of downregulation of these clustered miRNAs are still obscure.

To better understand and identify the anti-tumour targets of $m i R-216 b-3 p$ in PDAC cells, we have applied in silico database and genome-wide gene expression analyses. In this study, FOXQ1 (a member of the forkhead transcription factor family) was identified as a direct target of $m i R-216 b-3 p$ regulation in PDAC cells. Moreover, our functional studies revealed that expression of FOXQ1 promoted cancer cell aggressiveness, and overexpression of FOXQ1 was involved in PDAC pathogenesis. The FOX-family consists of a large number of transcription factors that have been categorized in 19 subfamilies, FOXA-FOXS [37, 38]. FOX transcription factors play pivotal roles in regulating the expression of genes involved in several biological processes [37, 38]. Numerous studies have demonstrated that FOXQ1 (as well as other FOX-family member) is associated with the progression, metastasis and drug resistance of human cancers [39].

The epithelial-mesenchymal transition (EMT) is pivotal in cancer cell invasion, metastasis and chemoresistance [40, 41]. Many EMT-promoting transcription factors have been implicated in these events in cancer cells $[40,41]$. In lung cancer cells, elimination of FOXQ1 affected the re-expression of epithelial markers and decreases mesenchymal markers in vitro and in vivo[42]. Similar studies reported that upregulation of FOXQ1 triggered EMT and contributed to metastasis and chemoresistance in several cancers [43-45]. The existence of cancer stem cells (CSCs) is an important concept in cancer cell aggressiveness, metastasis and chemoresistance [46]. In PDAC, CSCs were isolated based on expression of CD44, CD133 and EpCAM. Overexpression of FOXQ1 was detected in CSCs and CSCs behaver have more aggressiveness for cell growth, compared with parental MiaPaCa-2 cells [47].

A large number of cohort analyses of the TCGA dataset showed that high expression of FOXQ1 predicted shortened survival of patients with PDAC. Likewise, there are many reports that expression of $F O X Q 1$ indicates poor prognosis $[44,45,48]$. In this study, we identified "ECMreceptor interaction", "regulation of actin cytoskeleton" and "focal adhesion pathways" as FOXQ1-mediated downstream pathways in PDAC cells. Interestingly, among 41 downstream genes of FOXQ1, 13 genes were
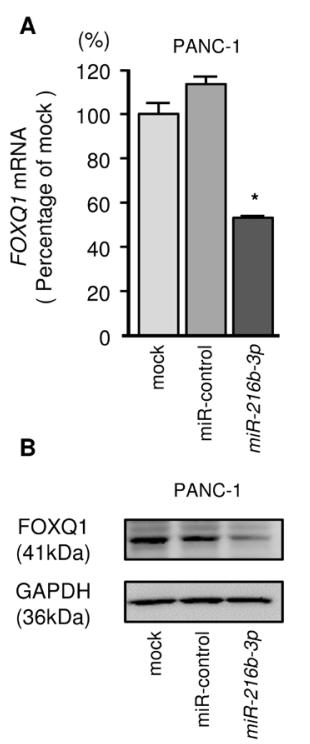
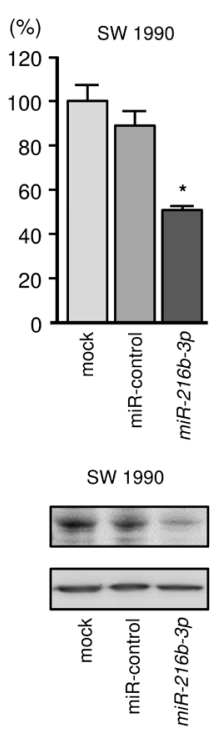

C

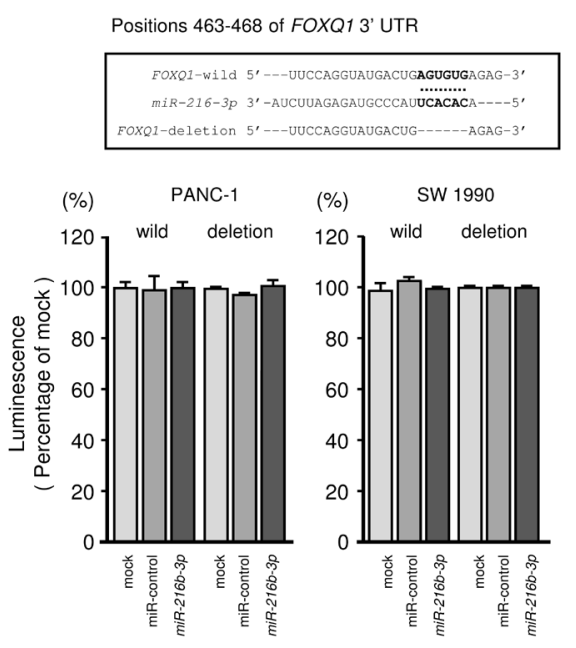

Positions 720-727 of FOXQ1 3' UTR
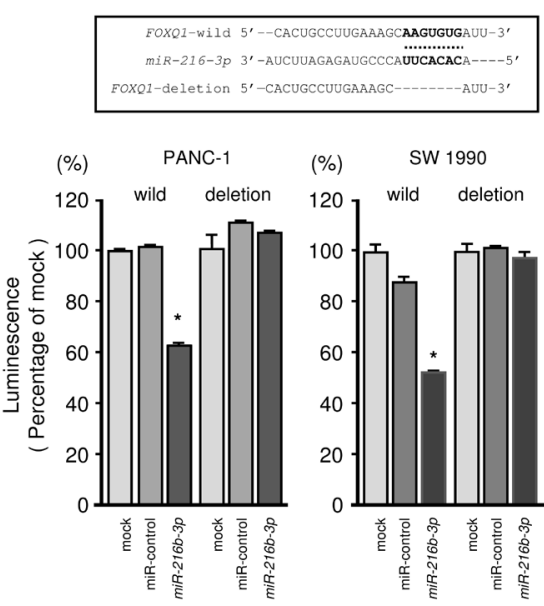

Figure 6: Direct regulation of FOXQ1 by $\boldsymbol{m i R}-216 \boldsymbol{b}-3 \boldsymbol{p}$ in PDAC cells. (A) FOXQ1 mRNA expression was evaluated using qRT-PCR in PANC-1 and SW 1990 cells $72 \mathrm{~h}$ after transfection with $m i R-216 b-3 p$. GUSB was used as an internal control. *, $P<0.0001$. (B) FOXQ1 protein expression was evaluated by Western blotting in PANC-1 and SW 1990 cells 72 to $96 \mathrm{~h}$ after transfection with $m i R$ 216b-3p. GAPDH was used as a loading control. (C) $m i R-216 b-3 p$ binding sites in the 3'-UTR of FOXQ1 mRNA. Dual luciferase reporter assays using vectors encoding putative miR-216b-3p target sites of the FOXQ1 3'-UTR (positions 463-468 and 720-727) for both wild-type and deleted regions. Data were normalized by expressing ratios of Renilla/firefly luciferase activities. *, $P<0.0001$. 
associated with poor prognosis of patients with PDAC by TCGA analyses. These findings suggest that expression of FOXQ1 and FOXQ1-mediated pathways contribute significantly to PDAC aggressiveness.

Our miRNA signature showed that $m i R-217$ was also markedly reduced in PDAC tissues. This miRNA is located in the same genomic region as the $m i R-216$ cluster. Our data showed that ectopic expression of $m i R$ 217 significantly inhibited cancer cell aggressiveness in PDAC cells by targeting focal adhesion pathways (data not shown). Past studies pointed to the anti-tumour function of $m i R-217$ in several cancers, including the targeting of the $K R A S$ oncogene in PDAC [49].
In conclusion, downregulation of 4 clustered miRNAs $\quad(m i R-216 a-5 p, \quad m i R-216 a-3 p, \quad m i R-216 b-5 p$ and $m i R-216 b-3 p$ ) was detected by RNA sequencingbased miRNA signature analysis. The tumour-suppressor functions of these miRNAs were shown in PDAC cells. The expression of FOXQ1 was directly regulated by $m i R$ $216 b-3 p$ and its overexpression was involved in PDAC pathogenesis. Identification of novel cancer networks mediated by aberrantly expressed miRNAs and tumoursuppressor miRNAs may improve our understanding of PDAC molecular pathogenesis. Our newly created RNA sequencing-based miRNA signature provides a basis for further PDAC research.
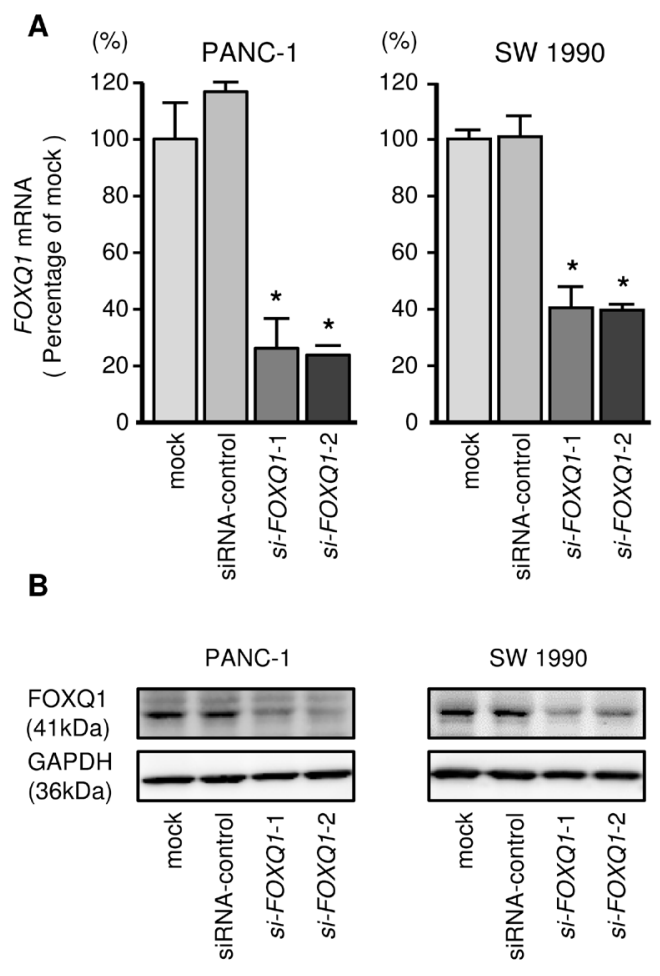
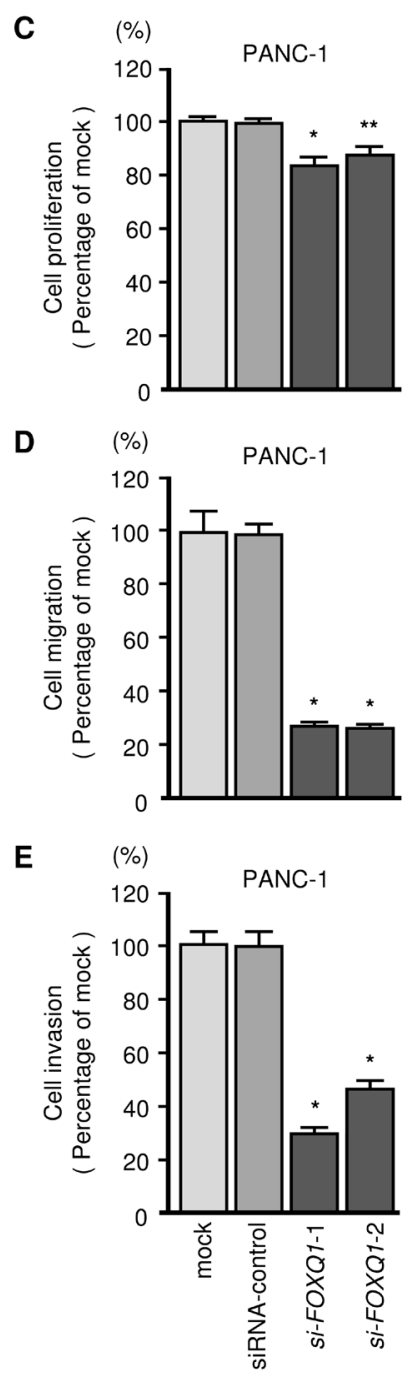
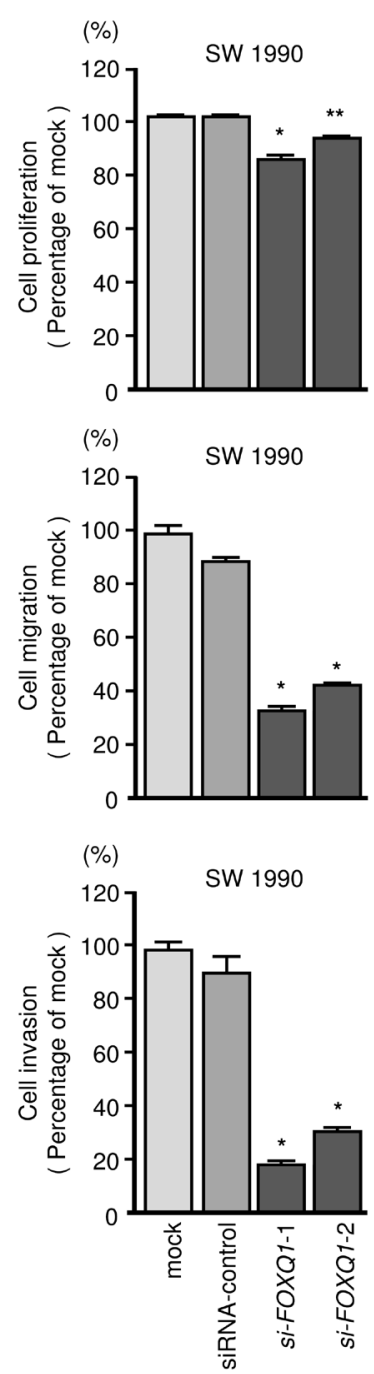

Figure 7: Effects of FOXQ1 silencing on PDAC cell lines. (A) FOXQ1 mRNA expression was evaluated using qRT-PCR analysis of PANC-1 and SW 1990 cells $72 \mathrm{~h}$ after transfection with si-FOXQ1-1 or si-FOXQ1-2. GUSB was used as an internal control. (B) FOXQ1 protein expression was evaluated using Western blotting analysis of PANC-1 and SW 1990 cells 72 to $96 \mathrm{~h}$ after transfection with miR216b-3p. GAPDH was used as a loading control. (C) Cell proliferation was determined using XTT assays $72 \mathrm{~h}$ after transfection with 10 nM si-FOXQ1-1 or si-FOXQ1-2. *, $P<0.0001$; **, $P<0.05$. (D) Cell migration activity was determined using BD Falcon Cell Culture Inserts. ${ }^{*}, P<0.0001$. (E) Cell invasion activity was determined using Matrigel invasion assays. ${ }^{*}, P<0.0001$. 


\section{MATERIALS AND METHODS}

\section{Clinical specimens and cell lines}

We used fresh $(n=24)$ and preserved (formalinfixed, paraffin-embedded blocks $)(\mathrm{n}=35)$ specimens for the current study. Tissues were obtained from PDAC patients who underwent surgery at Kagoshima University Hospital between 1991 and 2014. Normal pancreatic tissue specimens $(n=14)$ were collected from noncancerous tumour-adjacent tissue. Each surgical specimen was histologically classified according to the TNM classification system [50]. All patients in this study provided informed consent and the study protocol was approved by the Institutional Review Board of Kagoshima University. Patient information and clinicopathological features are shown in Table 1.

Two human PDAC cell lines were used in this study. PANC-1 cells were obtained from the RIKEN Cell Bank (Tsukuba, Ibaraki, Japan) and SW 1990 cells were obtained from the ATCC (Manassas, Virginia, USA).

\section{Construction of the miRNA expression signature in PDAC}

Total RNAs from 7 PDAC tissues and 4 normal pancreatic tissues were subjected to RNA sequencing. The construction procedure of miRNA signature included the following steps: small RNA isolation, cDNA library preparation and sequencing as described previously [14]

\section{Quantitative real-time RT-PCR}

Quantification of miRNA was performed using qRT-PCR as previously described [20, 28, 51, 52]. We used the following probes and primers: miR-216a-5p (product ID: 2220; Thermo Fisher Scientific, Waltham, MA, USA), miR-216a-3p (product ID: 475580_mat), $m i R-216 b-5 p$ (product ID: 2326), miR-216b-3p (product ID: 467177_mat), PLAU (product ID: Hs01547054 m1), GNB4 (product ID: Hs00222147_m1) and FOXQ1 (product ID: Hs00536425_s1. Human GUSB (product ID: Hs99999908_m1) and RNU48 (product ID: 001006) were used as internal controls.

\section{Transfection of miRNA mimic and small interfering RNA (siRNA) into PDAC cell lines}

PDAC cell lines were transfected with a miRNA mimic for gain-of-function experiments and siRNA for loss-of-function experiments. Pre-miR ${ }^{\mathrm{TM}}$ miRNA precursors for $m i R-216 a-5 p$ (product ID: PM10545; Thermo Fisher Scientific), miR-216a-3p (product ID: PM24316), miR-216b-5p (product ID: PM12302), miR- 216b-3p (product ID: PM28358), negative control miRNA (product ID: AM 17111), two FOXQ1 siRNAs (product IDs: s41290 and s41291) and control siRNA (product ID: D-001810-10) were purchased from Thermo Fisher Scientific. The transfection efficiencies of miRNA in PANC-1 and SW 1990 cells were calculated as described in previous studies [20, 28, 51, 52].

\section{Cell proliferation, migration and invasion assays}

Cell proliferation, migration and invasion assays were described previously [20, 28, 51, 52].

\section{Western blot analyses}

Mouse anti-FOXQ1 antibodies (product ID: sc166266; Santa Cruz Biotechnology, Inc., Dallas, TX, USA) were diluted 1:500 for immunoblotting. AntiGAPDH antibodies at a 1:1000 dilution (product ID: 010-25521; Wako, Osaka, Japan) were used as an internal loading control.

\section{Immunohistochemistry}

Tissue sections were incubated overnight at $4{ }^{\circ} \mathrm{C}$ with anti-FOXQ1 antibodies diluted 1:300 (product ID: ab51340; Abcam, Cambridge, UK). Cytoplasmic staining of FOXQ1 in at least $1 \%$ of cancer cells was classified as high. If no cancer cells were stained, specimens were classified as negative for FOXQ1 staining. The expression of FOXQ1 was evaluated in 10 fields of 100 cells each using high-power microscopy $(400 \times)$.

\section{Genome-wide gene expression and in silico analyses}

To identify $m i R-216 b-3 p$ target genes, a combination of genome-wide gene expression and in silico analyses was conducted as described previously [20, 28, 51, 52]. The microarray data were deposited into the Gene Omnibus database (GEO) repository under the accession number GSE82108. Next, we selected putative miRNA target genes using the TargetScanHuman (August, 2015 release, http://www.targetscan.org/vert_70) database.

\section{Construction of plasmid vectors and dual luciferase reporter assays}

Wild-type sequences of the 3'-UTR of FOXQ1 containing the $2 m i R-216 b-3 p$ target sites (positions $463-468$ or $720-727$ ) sequences or lacking a $m i R-216 b-$ $3 p$ target site were inserted in the psiCHECK-2 vector (product ID: C8021; Promega, Madison, WI, USA). The procedure was described previously $[20,28,51,52]$. 


\section{Identification of downstream targets regulated by FOXQ1 in PDAC}

Gene expression analyses of si-FOXQ1-transfected PANC-1 cells revealed molecular pathways and targets regulated by FOXQ1 in PDAC cells. This method was described in detail in previous studies [15, 20]. Microarray results were deposited in the GEO database (accession number GSE77790).

\section{Statistical analysis}

Relationships between expression values in 2 conditions or variables were analysed using the MannWhitney $\mathrm{U}$ test, and relationships between expression values in 3 conditions or variables were analysed using Bonferroni-adjusted Mann-Whitney U test. The correlation between the expression levels of $m i R-216 \mathrm{~b}-$ $3 p$ and $F O X Q 1$ was evaluated using Spearman's rank test. Associations between different categories were assessed using Fisher's exact test and the chi-squared test. Overall survival (OS) after surgery was gauged using KaplanMeier curves. Patients were divided into two groups based on FOXQ1 expression, and differences in survival were estimated using the log-rank test. We used Expert StatView software (version 5.0 SAS Institute Inc., Cary, $\mathrm{NC}, \mathrm{USA}$ ) for these analyses.

\section{ACKNOWLEDGMENTS}

We wish to thank the Joint Research Laboratory, Kagoshima University Graduate School of Medical and Dental Sciences, for the use of their facilities. The present study was supported by KAKENHI(C) grant 15K10801, 26462067.

\section{CONFLICTS OF INTEREST}

The authors declare no conflicts of interest.

\section{REFERENCES}

1. Polireddy K, Chen Q. Cancer of the pancreas: molecular pathways and current advancement in treatment. J Cancer. 2016; 7:1497-1514.

2. Ilic M, Ilic I. Epidemiology of pancreatic cancer. World J Gastroenterol. 2016; 22:9694-9705.

3. Das S, Batra SK. Pancreatic cancer metastasis: are we being pre-EMTed? Curr Pharm Des. 2015; 21:1249-1255.

4. Castellanos JA, Merchant NB. Intensity of follow-up after pancreatic cancer resection. Ann Surg Oncol. 2014; 21:747-751.

5. Chiorean EG, Coveler AL. Pancreatic cancer: optimizing treatment options, new, and emerging targeted therapies. Drug Des Devel Ther. 2015; 9:3529-3545.
6. Ahn DH, Williams TM, Goldstein DA, El-Rayes B, BekaiiSaab T. Adjuvant therapy for pancreas cancer in an era of value based cancer care. Cancer Treat Rev. 2016; 42:10-17.

7. Brunetti O, Russo A, Scarpa A, Santini D, Reni M, Bittoni A, Azzariti A, Aprile G, Delcuratolo S, Signorile M, Gnoni A, Palermo L, Lorusso V, Cascinu S, Silvestris N. MicroRNA in pancreatic adenocarcinoma: predictive/ prognostic biomarkers or therapeutic targets? Oncotarget. 2015; 6:23323-23341.

8. Salmanidis M, Pillman K, Goodall G, Bracken C. Direct transcriptional regulation by nuclear microRNAs. Int $\mathrm{J}$ Biochem Cell Biol. 2014; 54:304-311.

9. Kurozumi A, Goto Y, Okato A, Ichikawa T, Seki N. Aberrantly expressed microRNAs in bladder cancer and renal cell carcinoma. J Hum Genet. 2017; 62:49-56.

10. Mizuno K, Mataki H, Seki N, Kumamoto T, Kamikawaji $\mathrm{K}$, Inoue H. MicroRNAs in non-small cell lung cancer and idiopathic pulmonary fibrosis. J Hum Genet. 2017; 62:57-65.

11. Koshizuka K, Hanazawa T, Fukumoto I, Kikkawa N, Okamoto Y, Seki N. The microRNA signatures: aberrantly expressed microRNAs in head and neck squamous cell carcinoma. J Hum Genet. 2017; 62:3-13.

12. Yonemori K, Kurahara H, Maemura K, Natsugoe S. MicroRNA in pancreatic cancer. J Hum Genet. 2017; 62:33-40.

13. Fukumoto I, Kinoshita T, Hanazawa T, Kikkawa N, Chiyomaru T, Enokida H, Yamamoto N, Goto Y, Nishikawa R, Nakagawa M, Okamoto Y, Seki N. Identification of tumour suppressive microRNA-451a in hypopharyngeal squamous cell carcinoma based on microRNA expression signature. Br J Cancer. 2014; 111:386-394.

14. Itesako T, Seki N, Yoshino H, Chiyomaru T, Yamasaki T, Hidaka H, Yonezawa T, Nohata N, Kinoshita T, Nakagawa M, Enokida H. The microRNA expression signature of bladder cancer by deep sequencing: the functional significance of the miR-195/497 cluster. PLoS One. 2014; 9:e84311.

15. Fukumoto I, Hanazawa $\mathrm{T}$, Kinoshita $\mathrm{T}$, Kikkawa N, Koshizuka K, Goto Y, Nishikawa R, Chiyomaru T, Enokida H, Nakagawa M, Okamoto Y, Seki N. MicroRNA expression signature of oral squamous cell carcinoma: functional role of microRNA-26a/b in the modulation of novel cancer pathways. Br J Cancer. 2015; 112:891-900.

16. Goto Y, Kojima S, Nishikawa R, Kurozumi A, Kato M, Enokida H, Matsushita R, Yamazaki K, Ishida Y, Nakagawa M, Naya Y, Ichikawa T, Seki N. MicroRNA expression signature of castration-resistant prostate cancer: the microRNA-221/222 cluster functions as a tumour suppressor and disease progression marker. $\mathrm{Br} \mathrm{J}$ Cancer. 2015; 113:1055-1065.

17. Fuse M, Kojima S, Enokida H, Chiyomaru T, Yoshino H, Nohata N, Kinoshita T, Sakamoto S, Naya Y, Nakagawa M, Ichikawa T, Seki N. Tumor suppressive microRNAs 
(miR-222 and miR-31) regulate molecular pathways based on microRNA expression signature in prostate cancer. $\mathrm{J}$ Hum Genet. 2012; 57:691-699.

18. Nohata N, Hanazawa T, Kikkawa N, Sakurai D, Fujimura L, Chiyomaru T, Kawakami K, Yoshino H, Enokida H, Nakagawa M, Katayama A, Harabuchi Y, Okamoto Y, Seki N. Tumour suppressive microRNA-874 regulates novel cancer networks in maxillary sinus squamous cell carcinoma. Br J Cancer. 2011; 105:833-841.

19. Kikkawa N, Hanazawa T, Fujimura L, Nohata N, Suzuki H, Chazono H, Sakurai D, Horiguchi S, Okamoto Y, Seki N. miR-489 is a tumour-suppressive miRNA target PTPN11 in hypopharyngeal squamous cell carcinoma (HSCC). Br J Cancer. 2010; 103:877-884.

20. Goto Y, Kurozumi A, Nohata N, Kojima S, Matsushita R, Yoshino H, Yamazaki K, Ishida Y, Ichikawa T, Naya Y, Seki N. The microRNA signature of patients with sunitinib failure: regulation of UHRF1 pathways by microRNA-101 in renal cell carcinoma. Oncotarget. 2016; 7:59070-59086. https://doi.org/10.18632/oncotarget.10887.

21. Matsushita R, Yoshino H, Enokida H, Goto Y, Miyamoto K, Yonemori M, Inoguchi S, Nakagawa M, Seki N. Regulation of UHRF1 by dual-strand tumor-suppressor microRNA-145 (miR-145-5p and miR-145-3p): inhibition of bladder cancer cell aggressiveness. Oncotarget. 2016; 7:28460-28487. https://doi.org/10.18632/oncotarget.8668.

22. Mataki H, Seki N, Mizuno K, Nohata N, Kamikawaji K, Kumamoto T, Koshizuka K, Goto Y, Inoue H. Dual-strand tumor-suppressor microRNA-145 (miR-145-5p and miR145-3p) coordinately targeted MTDH in lung squamous cell carcinoma. Oncotarget. 2016; 7:72084-72098. https://doi. org/10.18632/oncotarget.12290.

23. Yonemori M, Seki N, Yoshino H, Matsushita R, Miyamoto K, Nakagawa M, Enokida H. Dual tumor-suppressors miR139-5p and miR-139-3p targeting matrix metalloprotease 11 in bladder cancer. Cancer Sci. 2016; 107:1233-1242.

24. Anaya J. OncoLnc: linking TCGA survival data to mRNAs, miRNAs, and lncRNAs. PeerJ CompSci. 2016; 2:e67.

25. Ali S, Saleh H, Sethi S, Sarkar FH, Philip PA. MicroRNA profiling of diagnostic needle aspirates from patients with pancreatic cancer. Br J Cancer. 2012; 107:1354-1360.

26. Schultz NA, Werner J, Willenbrock H, Roslind A, Giese N, Horn T, Wojdemann M, Johansen JS. MicroRNA expression profiles associated with pancreatic adenocarcinoma and ampullary adenocarcinoma. Mod Pathol. 2012; 25:1609-1622.

27. Hong TH, Park IY. MicroRNA expression profiling of diagnostic needle aspirates from surgical pancreatic cancer specimens. Ann Surg Treat Res. 2014; 87:290-297.

28. Yonemori K, Seki N, Kurahara H, Osako Y, Idichi T, Arai T, Koshizuka K, Kita Y, Maemura K, Natsugoe S. ZFP36L2 promotes cancer cell aggressiveness and is regulated by antitumor microRNA-375 in pancreatic ductal adenocarcinoma. Cancer Sci. 2017; 108:124-135.
29. Hou BH, Jian ZX, Cui P, Li SJ, Tian RQ, Ou JR. miR-216a may inhibit pancreatic tumor growth by targeting JAK2. FEBS Lett. 2015; 589:2224-2232.

30. Deng M, Tang H, Zhou Y, Zhou M, Xiong W, Zheng Y, Ye Q, Zeng X, Liao Q, Guo X, Li X, Ma J, Li G. miR$216 \mathrm{~b}$ suppresses tumor growth and invasion by targeting KRAS in nasopharyngeal carcinoma. J Cell Sci. 2011; 124:2997-3005.

31. Diederichs S, Haber DA. Dual role for argonautes in microRNA processing and posttranscriptional regulation of microRNA expression. Cell. 2007; 131:1097-1108.

32. Matranga C, Tomari Y, Shin C, Bartel DP, Zamore PD. Passenger-strand cleavage facilitates assembly of siRNA into Ago2-containing RNAi enzyme complexes. Cell. 2005; 123:607-620.

33. di Magliano MP, Logsdon CD. Roles for KRAS in pancreatic tumor development and progression. Gastroenterology. 2013; 144:1220-1229.

34. Eser S, Schnieke A, Schneider G, Saur D. Oncogenic KRAS signalling in pancreatic cancer. Br J Cancer. 2014; 111:817-822.

35. Azevedo-Pouly AC, Sutaria DS, Jiang J, Elgamal OA, Amari F, Allard D, Grippo PJ, Coppola V, Schmittgen TD. miR-216 and miR-217 expression is reduced in transgenic mouse models of pancreatic adenocarcinoma, knockout of miR-216/miR-217 host gene is embryonic lethal. Funct Integr Genomics. 2017; 17:203-212.

36. Rachagani S, Macha MA, Menning MS, Dey P, Pai P, Smith LM, Mo YY, Batra SK. Changes in microRNA (miRNA) expression during pancreatic cancer development and progression in a genetically engineered KrasG12D;Pdx1Cre mouse (KC) model. Oncotarget. 2015; 6:40295-40309. https://doi.org/10.18632/oncotarget.5641.

37. Jackson BC, Carpenter C, Nebert DW, Vasiliou V. Update of human and mouse forkhead box (FOX) gene families. Hum Genomics. 2010; 4:345-352.

38. Uhlenhaut NH, Treier M. Forkhead transcription factors in ovarian function. Reproduction. 2011; 142:489-495.

39. Li Y, Zhang Y, Yao Z, Li S, Yin Z, Xu M. Forkhead box Q1: a key player in the pathogenesis of tumors (Review). Int $\mathrm{J}$ Oncol. 2016; 49:51-58.

40. Gonzalez DM, Medici D. Signaling mechanisms of the epithelial-mesenchymal transition. Sci Signal. 2014; 7:re8.

41. Diaz VM, Vinas-Castells R, Garcia de Herreros A. Regulation of the protein stability of EMT transcription factors. Cell Adh Migr. 2014; 8:418-428.

42. Feng J, Xu L, Ni S, Gu J, Zhu H, Wang H, Zhang S, Zhang W, Huang J. Involvement of FoxQ1 in NSCLC through regulating EMT and increasing chemosensitivity. Oncotarget. 2014; 5:9689-9702. https://doi.org/10.18632/ oncotarget.2103.

43. Zhu Z, Zhu Z, Pang Z, Xing Y, Wan F, Lan D, Wang H. Short hairpin RNA targeting FOXQ1 inhibits invasion 
and metastasis via the reversal of epithelial-mesenchymal transition in bladder cancer. Int J Oncol. 2013; 42:1271-1278.

44. Xia L, Huang W, Tian D, Zhang L, Qi X, Chen Z, Shang X, Nie Y, Wu K. Forkhead box Q1 promotes hepatocellular carcinoma metastasis by transactivating ZEB2 and VersicanV1 expression. Hepatology. 2014; 59:958-973.

45. Zhang J, Liu Y, Zhang J, Cui X, Li G, Wang J, Ren H, Zhang Y. FOXQ1 promotes gastric cancer metastasis through upregulation of Snail. Oncol Rep. 2016; 35:3607-3613.

46. Geng SQ, Alexandrou AT, Li JJ. Breast cancer stem cells: multiple capacities in tumor metastasis. Cancer Lett. 2014; 349:1-7.

47. Bao B, Azmi AS, Aboukameel A, Ahmad A, Bolling-Fischer A, Sethi S, Ali S, Li Y, Kong D, Banerjee S, Back J, Sarkar FH. Pancreatic cancer stem-like cells display aggressive behavior mediated via activation of FoxQ1. J Biol Chem. 2014; 289:14520-14533.

48. Feng J, Zhang X, Zhu H, Wang X, Ni S, Huang J. FoxQ1 overexpression influences poor prognosis in non-small cell lung cancer, associates with the phenomenon of EMT. PLoS One. 2012; 7:e39937.
49. Zhao WG, Yu SN, Lu ZH, Ma YH, Gu YM, Chen J. The miR-217 microRNA functions as a potential tumor suppressor in pancreatic ductal adenocarcinoma by targeting KRAS. Carcinogenesis. 2010; 31:1726-1733.

50. Sobin LH, Gospodarowicz MK, Wittekind C. (2009). International Union Against Cancer (UICC) TNM Classification of Malignant Tumors. 7th ed. (Oxford, UK: Wiley-Blackwell).

51. Koshizuka K, Hanazawa T, Fukumoto I, Kikkawa N, Matsushita R, Mataki H, Mizuno K, Okamoto Y, Seki N. Dual-receptor (EGFR and c-MET) inhibition by tumorsuppressive miR-1 and miR-206 in head and neck squamous cell carcinoma. J Hum Genet. 2017; 62:113-121.

52. Osako Y, Seki N, Kita Y, Yonemori K, Koshizuka K, Kurozumi A, Omoto I, Sasaki K, Uchikado Y, Kurahara H, Maemura K, Natsugoe S. Regulation of MMP13 by antitumor microRNA-375 markedly inhibits cancer cell migration and invasion in esophageal squamous cell carcinoma. Int J Oncol. 2016; 49: 2255-2264. 